\title{
17. PLAGIOCLASE-BEARING ULTRAMAFIC TECTONITES FROM THE GALICIA MARGIN (LEG 103, SITE 637): COMPARISON OF THEIR ORIGIN AND EVOLUTION WITH LOW-PRESSURE ULTRAMAFIC BODIES IN WESTERN EUROPE1
}

\author{
Jacques Kornprobst and Abdelhalim Tabit, Centre de Recherches Volcanologiques, OPGC et UA 10 (Université de \\ Clermont II), Clermont Ferrand, France
}

\begin{abstract}
Mineral compositions of the plagioclase-bearing ultramafic tectonites dredged and cored seaward of the continental slope of the Galicia margin (Leg 103, Site 637) were compared to mineral compositions from onshore low-pressure ultramafic bodies (southeastern Ronda, western Pyrenees, and Lizard Point), on the basis of standardized (30-s counting time) probe analyses. The comparison was extended to some plagioclase-free harzburgites related to ophiolites (Santa Elena in Costa Rica, north Oman, and the Humboldt body in New Caledonia) on the basis of new analytical data and data from the literature. The behavior of $\mathrm{Cr}, \mathrm{Na}, \mathrm{Al}, \mathrm{Mg}, \mathrm{Fe}, \mathrm{Ni}$, and $\mathrm{Ti}$ in olivine, pyroxenes, and spinel was examined in order to distinguish between the effects of partial melting and mineral facies change, from the spinel to plagioclase stability fields.

The peridotite from the Galicia margin appears slightly depleted in major incompatible elements and experienced a minor partial melting. However, it experienced large scale but heterogeneous recrystallization in the plagioclase field. These features are very similar to those observed in Ronda, whereas in the western Pyrenees the minerals exemplify a very minor partial-melting event (or none at all) and have retained compositions corresponding to those of the relatively high-pressure Seiland subfacies. The minerals from the Lizard Point peridotite have characteristics (low $\mathrm{Mg} /(\mathrm{Mg}+\mathrm{Fe})$ ratio; high $\mathrm{Cr} /(\mathrm{Cr}+\mathrm{Al})$ ratio in spinel) more related to cumulate from a differentiated tholeitic melt than related to ophiolitic tectonite.

Diffusion profiles of $\mathrm{Al}$ and $\mathrm{Cr}$ across pyroxenes and spinel show that recrystallization features occurred at different speeds or temperatures in the different bodies. The pyroxenes from Ronda would have experienced recrystallization about 14 times faster than the peridotite from the Galicia margin. The western Pyrenean lherzolites also experienced rapid recrystallization; nevertheless, because they are of a different mineral facies, the data are not directly comparable to that from Ronda and Galicia. The harzburgite at Santa Elena as well as a xenolith from alkali basalt exemplify rapid cooling characterized by very weak re-equilibration.

Recrystallization speed is related to emplacement speed in the present geological environment. The slow-rising Galicia margin peridotite was emplaced by thinning of the lithospheric subcontinental mantle near an incipient mid-oceanic ridge. The fast-rising peridotites from Ronda and the western Pyrenees were hot diapirs emplaced from the asthenosphere along transcurrent faults, possibly related to the opening of the Atlantic Ocean.
\end{abstract}

\section{INTRODUCTION}

Different types of 4- or 5-phase peridotites (lherzolites or harzburgites involving olivine + orthopyroxene + clinopyroxene + spinel and/or plagioclase) correspond to different origins and modes of emplacement. Some are relatively low-pressure fractionation products of basic melts (ultramafic units of crustal layered intrusions-Jackson, 1961; or crustal igneous units of the ophiolite pile-Coleman, 1977). Most of these experienced geodynamic evolution and deformation in the solid state. They are interpreted as (1) refractory residues after extensive partial melting of fertile mantle along accretion zones (mantle harzburgite at the bottom of the ophiolitic pile; Coleman, 1977), (2) ultramafic intrusions (mantle "diapirs") that originated at depth (in the asthenosphere) and were associated with thermal anomalies and minor melting (high-temperature orogenic bodies; Green, 1964; Kornprobst, 1969; Dickey, 1970; Nicolas et al., 1987), and (3) lithospheric ultramafic units that equilibrated at shallow depth in the mantle and were uplifted during extension processes (lithospheric thinning). From its original description (Boillot et al., 1980, 1985) the plagioclase-bearing ultramafic tectonite from the Galicia margin would belong to the latter type.

${ }^{1}$ Boillot, G., Winterer, E. L., et al., 1988. Proc. ODP, Sci. Results, 103: College Station, TX (Ocean Drilling Program).
This work presents electron microprobe data on the "primary assemblage" (prior to serpentinization) of the Galicia margin peridotites and compares them to mineralogical features of ultramafic units from various other geological environments. The aim of the paper is to characterize the dynamic behavior of such ultramafic rocks on the basis of their mineral composition and zoning.

\section{ULTRAMAFIC SUITES SELECTED FOR COMPARISON}

\section{Plagioclase-Bearing Peridotites at Site 637}

Eight samples (Table 1) were chosen for microprobe analysis from the Site 637 peridotite. All of the samples were highly serpentinized and calcitized peridotites (harzburgites or lherzolites) involving less than $10 \%$ of the primary phases. Most samples were characterized by fresh plagioclase-or by typical secondary products after plagioclase-closely related to chromium-rich spinel and associated with orthopyroxene and clinopyroxene. Fresh olivine was detected in only one sample. More extensive descriptions of the rock types (i.e., mineralogy, textures, and geochemistry) are given in other chapters in this volume (Girardeau et al.; Evans and Girardeau; Agrinier et al.). The peridotites at Hill 5100, drilled at Site 637, were previously considered to be mantle rocks probably related to subcontinental (lithospheric) mantle (Boillot et al., 1980). The occurrence of plagioclase relates the rocks to relatively low-pressure (less than $8 \mathrm{kbar}$, i.e., 
Table 1. Peridotite samples studied from Site 637.

\begin{tabular}{|c|c|c|c|c|c|c|}
\hline \multirow[b]{2}{*}{ Code } & \multirow[b]{2}{*}{ Sample } & \multicolumn{5}{|c|}{ Fresh primary minerals } \\
\hline & & $\mathrm{Ol}$ & Opx & $\mathrm{Cpx}$ & $\mathrm{Sp}$ & Pl \\
\hline G4 & 103-637A-25R-2, 65-67 cm & & + & + & + & \\
\hline G8 & $25 \mathrm{R}-4,106-108 \mathrm{~cm}$ & & + & + & + & \\
\hline G11 & $26 \mathrm{R}-1,26-27 \mathrm{~cm}$ & & + & + & + & \\
\hline G12 & $26 \mathrm{R}-2,107-109 \mathrm{~cm}$ & & + & + & + & \\
\hline G13 & $26 \mathrm{R}-3,0-3 \mathrm{~cm}$ & & + & + & + & \\
\hline G14 & $27 \mathrm{R}-1,126-130 \mathrm{~cm}$ & & + & + & + & \\
\hline G16 & $27 \mathrm{R}-2,58-61 \mathrm{~cm}$ & & + & + & + & \\
\hline G19 & $27 \mathrm{R}-3,42-46 \mathrm{~cm}$ & + & + & + & + & + \\
\hline
\end{tabular}

Note: $\mathrm{Ol}=$ olivine; $\mathrm{Opx}=$ orthopyroxene; $\mathrm{Cpx}=$ clinopyroxene; $\mathrm{Sp}=$ spinel; $\mathrm{Pl}=$ plagioclase.

$25 \mathrm{~km}$ depth) recrystallization features. The relatively high temperatures $\left(1000^{\circ}\right.$ to $\left.1100^{\circ} \mathrm{C}\right)$ recorded by the pyroxenes during the development of the foliation (Girardeau et al., this volume) indicate that the rocks probably reached the partial-melting isograd during their emplacement, thus gaining the rheological properties of asthenosphere. In a recent report, Boillot et al. (1985) mentioned the alternative possibility that the peridotites originated from an old Hercynian ophiolitic unit.

In order to clarify the origin and evolution of the serpentinized peridotites at Site 637 , the characteristics of their primary minerals are compared with those of ultramafic bodies that experienced partial-melting events and/or solid-state recrystallization at relatively low pressure within the Seiland subfacies or plagioclase lherzolite facies (O'Hara, 1967) and with those of plagioclase-free ultramafic tectonites clearly related to ophiolites.

\section{Bodies Recrystallized in the Seiland Subfacies or Plagioclase-Lherzolite Facies Fields}

The two main bodies belonging to this group are geographically close to the ultramafic ridge drilled on the Galicia margin during Leg 103 (Fig. 1): the southeastern part of the Ronda Massif (Andalusia, Spain) and the western outcrops of lherzolite in the northern Pyrenean Zone (Basses Pyrénées, France). A third important body is observed at Lizard Point (Cornwall, U.K.). The first two bodies are closely related, as is the Galicia margin, to the "Alpine-Atlantic" history of western Europe. The latter's evolution, on the contrary, was restricted to the Hercynian orogeny.

\section{The Ronda Massif}

The Ronda Massif belongs to the Betico-Rifean ultramafic cluster (Beni Bouchera and Ceuta in Morocco; Ronda and Ojen in southern Spain). The assemblages grade, from northwest to southeast, from high- to low-pressure fields (Didon et al., 1973; Darot, 1973); the southeastern part of the massif was recrystallized principally in the plagioclase-lherzolite facies. Like the ultramafic rocks at Beni Bouchera, the peridotites are believed to have been emplaced as diapirs from a relatively great depth (Kornprobst, 1969; Dickey, 1970; Loomis, 1972), and probably represent asthenospheric, rather than lithospheric, mantle (Kornprobst et al., 1987a). Relatively rapid ascent was associated with a small amount of partial melting (Kornprobst, 1969; Dickey, 1970; Loubet et al., 1975; Frey et al., 1985). Low-pressure secondary assemblages involving plagioclase formed during the late stages of high-temperature emplacement when the peridotites were thrust over outer continental crustal units (Lundeen, 1978; Tubia and Cuevas, 1986).

\section{Western Ultramafic Bodies of the Pyrenees}

The Pyrenean lherzolites crop out as small ( 1 ha to $1 \mathrm{~km}^{2}$ ) bodies scattered along the northern Pyrenean Zone (Monchoux,

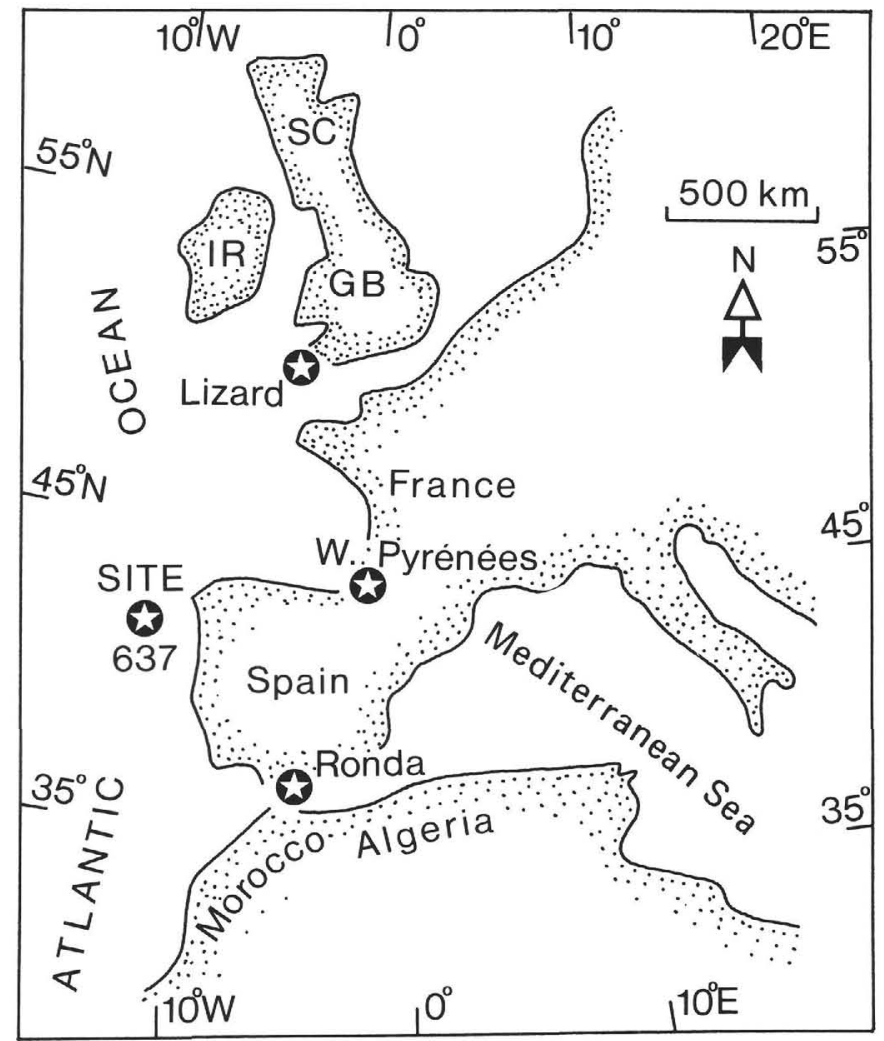

Figure 1. Location of low-pressure ultramafic bodies in western Europe. Harzburgites related to ophiolites (northern Oman, New Caledonia, and Costa Rica) are beyond the map boundaries. GB = Great Britain; $\mathrm{SC}=$ Scotland; IR = Ireland.

1970). Most exhibit high-pressure assemblages of the ariegite subfacies (Conquéré, 1977a, 1977b), but the western bodies show more or less advanced low-pressure recrystallization features in the Seiland subfacies or plagioclase-lherzolite facies (Rio, 1966; Gaudichet, 1974). The geotectonic significance of these ultramafic bodies is still debated. They originated from the mantle (Ravier, 1964) and have been closely compared to the Betico-Rifean cluster in view of their emplacement by crustal splitting along transcurrent faults (Vielzeuf and Kornprobst, 1984; Kornprobst and Vielzeuf, 1984). A hot alpine diapir rising directly from depth is suggested by this model. Nevertheless, an equilibration stage under the conditions of the lithospheric upper mantle $\left(950^{\circ} \mathrm{C}, 13-15\right.$ kbar; Conquéré and Fabriès, 1984a, 1984b) gave rise to a two-stage emplacement hypothesis. On the other hand, some stratigraphic arguments would lead one to consider at least the western bodies as the basement of sedimentary deposits prior to Middle Jurassic (Fortané et al., 1986). From the latter viewpoint, Boillot (1986) considered the Pyrenean lherzolites to have the same geotectonic significance as the peridotites from the Galicia margin (Boillot et al., 1980, 1985), that is, lithospheric upper mantle uplifted by denudation during pre-alpine extension.

\section{The Ultramafic Body at Lizard Point (Cornwall)}

This body was described 20 yr ago as a typical high-temperature ultramafic intrusion from the upper mantle (Green, 1964). More recently, the ultramafic and associated mafic rocks have been interpreted as an ophiolite on the basis of textural, mineralogical, and geochemical observations (Rothstein, 1971, 1977, 1981; Floyd, 1976; Kirby, 1979; Styles and Kirby, 1980). Some inconsistencies arise in the interpretation of the ultramafic unit, 
for which cumulate textures were described by Rothstein (1971, $1977,1981)$ whereas others considered the rocks to be the tectonites of the ophiolitic pile (Kirby, 1979). In fact, the high-temperature fabric (Green, 1964; Rothstein, 1981) related to the crystallization of secondary plagioclase, as well as the highpressure conditions ( $15 \mathrm{kbar})$ calculated from the primary associations (Vearncombe, 1980), are not commonly observed in ophiolitic igneous units. Also, as emphasized in the following comparison of compositions, the minerals of these peridotites have especially low $\mathrm{Mg} /(\mathrm{Mg}+\mathrm{Fe})$ ratios, which are lower than in any tectonite known from an ophiolitic environment. In spite of these uncertainties, the ultramafic body at Lizard Point is generally considered as part of an important oceanic marker in the Hercynian belt (Matte, 1986).

\section{Plagioclase-Free Harzburgites Related to Ophiolites}

Three occurrences of plagioclase-free and clinopyroxene-poor peridotites are considered here, mainly based on data from the literature. These rocks exhibit marked tectonic features and fabrics, and they are generally considered as mantle tectonites strongly depleted in incompatible elements because of an extensive partial melting.

1. The harzburgite from northern Oman ophiolite (Reinhardt, 1969) was described as a depleted mantle sequence (Boudier and Coleman, 1981). It is distinguished from the crustal sequence (igneous ultramafic and gabbroic cumulates) by a distinct petrological Moho characterized by a dunite layer that is interpreted as the early cumulate phase sequence of the igneous pile (Augé, 1983).

2. The harzburgite from the Humboldt Massif (New Caledonia) belongs to the mantle ultramafic tectonites (Podvin, 1983) that appear at the bottom of the peri-Australian ophiolitic belt (Aubouin et al., 1977). As in northern Oman, the petrological Moho is marked by a dunite layer interpreted here as the residue of incongruent melting of orthopyroxene (Prinzhofer, 1981).

3. The harzburgite from Santa Elena Peninsula (Costa Rica) is the main part of an ultramafic/mafic unit that was thrust over Mesozoic volcano-sedimentary rocks of oceanic affinity (Tournon, 1984). Although the original superposition and contacts were not preserved during the tectonic events, the main sequences of an ophiolitic pile are recognizable. Thus, the harzburgite can be interpreted as mantle tectonites, although it is possibly deformed igneous cumulates (Tournon, 1984).

\section{COMPARISON BETWEEN THE MINERAL COMPOSITIONS OF THE GALICIA MARGIN PERIDOTITES AND OTHER OCCURRENCES (TABLES 2 AND 3)}

Minerals in peridotites undergo compositional changes as a result of major petrological events such as a change in mineral facies or the occurrence and extent of partial melting. The transition from spinel- to plagioclase-lherzolite facies involves increasing the concentrations in pyroxenes and spinel of elements that do not enter substantially into secondary plagioclase and olivine. When partial melting occurs, minerals in the residual solid are depleted in incompatible elements and enriched in compatible elements. The partitioning of these elements between phases depends on the pressure and temperature conditions. Titanium is an incompatible element that cannot enter either the olivine or plagioclase lattice; the behavior of this element is a clue in separating the effects of melting from the effects of mineral facies change.

The peridotites from the Galicia margin experienced recrystallization at decreasing pressure related to crystallization of secondary plagioclase (Boillot et al., 1980, 1985). In the follow- ing discussion, the extent of depletion in these ultramafic samples, relative to oceanic harzburgites, is evaluated.

\section{Jadeite Content in Clinopyroxene and the $\mathrm{Al}^{\mathrm{iv}} / \mathrm{Al}^{\mathrm{vi}}$ Ratio}

As exemplified by the Ronda Massif, the $\mathrm{Na}$ content of clinopyroxene decreases and $\mathrm{Cr}$ content increases when the mineral facies changes from spinel to plagioclase facies. However, the depleted harzburgites from oceanic lithosphere have clinopyroxene especially poor in $\mathrm{Na}$ and rich in $\mathrm{Cr}$ with respect to clinopyroxene from peridotites related to the continental lithosphere (Kornprobst et al., 1981). Clinopyroxenes in the Galicia margin samples have relatively low $\mathrm{Na}$ concentrations, although these concentrations are sufficient to calculate the jadeite component (except for one analysis). This, along with a positive correlation between $\mathrm{Cr}$ and $\mathrm{Na}$ (Fig. 2A), suggests a complete recrystallization in the plagioclase field. This behavior differs from that of the Ronda Massif plagioclase peridotite in which some clinopyroxene crystals retained a relatively high jadeite content from the spinel facies stage of their evolution. The clinopyroxenes from Saraillhé (Seiland subfacies) are much richer in jadeite and recrystallized under relatively higher pressures (and/or lower temperatures) than the Galicia margin peridotites. As expected, the clinopyroxene from the Oman harzburgite is very poor in Na.

Composition varies significantly within each sample from the Galicia margin (Fig. 2B). Because crystal zoning does not show a very clear pattern (the lowest concentration of $\mathrm{Cr}$ analyzed is at the margin of the grain as a result of decreasing $\mathrm{P}$ and T), this is considered to be the result of variable amounts of partial melting as well as variable recrystallization within the plagioclase field.

Clinopyroxenes from Saraillhé have relatively high $\mathrm{Al}^{\mathrm{iv}} / \mathrm{Al}^{\mathrm{vi}}$ ratios (Fig. 3A), in agreement with a relatively high pressure of recrystallization and lack of plagioclase in the peridotites (Seiland subfacies). The Ronda clinopyroxenes have widely scattered ratios resulting from different amounts of recrystallization in the plagioclase field. Clinopyroxenes from the Galicia margin have $\mathrm{Al}^{\mathrm{iv}} / \mathrm{Al}^{\mathrm{vi}}$ ratios close to 1 , as do the clinopyroxenes from Santa Elena, Lizard, and northern Oman. The very low Al concentration in clinopyroxene from the northern Oman harzburgite is related to extensive partial melting. Therefore, the rough correlation of $\mathrm{Al}^{\mathrm{iv}}$ to $\mathrm{Al}^{\mathrm{vi}}$ exemplified by all these samples (and especially by the samples from the Galicia margin; Fig. 3B) and the evolution of a phenoclast preserved from the core to margin (Fig. 3C) can be interpreted as the result of either increasing partial melting toward the low concentrations of $\Sigma \mathrm{Al}$ or decreasing temperature and pressure, as would result from the following reactions:

\section{Ca-Tschermak + olivine $=$ diopside + enstatite + spinel $\mathrm{Ca}$-Tschermak + enstatite $=$ anorthite + olivine}

\section{Behavior of $\mathrm{Ni}, \mathrm{Mg}$, and $\mathrm{Cr}$ vs. $\mathrm{Fe}, \mathrm{Al}, \mathrm{Ti}$, and $\mathrm{Na}$}

The elements $\mathrm{Ni}, \mathrm{Mg}, \mathrm{Cr}, \mathrm{Fe}, \mathrm{Al}$, and $\mathrm{Na}$ play similar roles in peridotites during partial melting or during transition from spinel to plagioclase facies. This is not the case for $\mathrm{Ti}$, which is incompatible and does not enter either the olivine or plagioclase crystal lattice.

\section{$\mathrm{Ni}$ and $\mathrm{Mg}$ in Olivine (Fig. 4)}

The concentration range of $\mathrm{Ni}$ and $\mathrm{Mg}$ in olivine is large. Although the olivines from northern Oman appear more depleted (i.e., richer in $\mathrm{Mg}$ ) than the olivine from the western Pyrenees, the two fields overlap. The data given in Figure 4 show that it is 
Table 2. Selected analyses of clinopyroxenes, orthopyroxenes, and spinels from the Site 637 peridotites. Electron microprobe CAMEBAX (Centre de Mesures Physique, Université de Clermont II). Acceleration voltage $=15 \mathrm{kV}$; current $=11$ $\mathrm{nA}$; counting time $=\mathbf{3 0} \mathrm{s}$. Sample identifications for ODP samples are given in Table 1.

\begin{tabular}{|c|c|c|c|c|c|c|c|c|}
\hline Mineral & G4 & G8 & G11 & G12 & G13 & G14 & G16 & G19 \\
\hline \multicolumn{9}{|c|}{ Clinopyroxenes } \\
\hline $\mathrm{SiO}_{2}$ & 52.58 & 52.20 & 53.16 & 53.29 & 52.64 & 52.01 & 52.24 & 51.75 \\
\hline $\mathrm{Al}_{2} \mathrm{O}_{3}$ & 4.50 & 5.31 & 4.99 & 3.74 & 3.21 & 5.36 & 4.40 & 4.72 \\
\hline $\mathrm{Cr}_{2} \mathrm{O}_{3}$ & 0.96 & 1.27 & 1.60 & 0.72 & 0.75 & 1.27 & 0.97 & 0.93 \\
\hline $\mathrm{TiO}_{2}$ & 0.41 & 0.59 & 0.29 & 0.42 & 0.39 & 0.14 & 0.40 & 0.70 \\
\hline${ }^{\mathrm{a}} \mathrm{FeO}$ & 2.29 & 1.99 & 1.89 & 2.07 & 2.06 & 2.17 & 2.14 & 2.39 \\
\hline $\mathrm{MgO}$ & 16.29 & 16.02 & 15.28 & 16.61 & 16.56 & 15.73 & 15.99 & 16.11 \\
\hline $\mathrm{MnO}$ & 0.07 & 0.11 & 0.04 & 0.31 & 0.06 & 0.08 & 0.11 & 0.05 \\
\hline $\mathrm{NiO}$ & 0.18 & 0.01 & 0.00 & 0.02 & 0.06 & 0.02 & 0.06 & 0.05 \\
\hline $\mathrm{CaO}$ & 22.54 & 22.91 & 22.24 & 22.56 & 23.17 & 22.27 & 22.82 & 22.68 \\
\hline $\mathrm{Na}_{2} \mathrm{O}$ & 0.68 & 0.82 & 1.23 & 0.69 & 0.55 & 0.86 & 0.60 & 0.55 \\
\hline $\mathrm{K}_{2} \mathrm{O}$ & 0.00 & 0.00 & 0.00 & 0.06 & 0.02 & 0.01 & 0.01 & 0.00 \\
\hline Total & 100.50 & $\overline{101.23}$ & 100.72 & 100.49 & 99.47 & 99.92 & 99.74 & 99.93 \\
\hline \multicolumn{9}{|c|}{ Orthopyroxenes } \\
\hline $\mathrm{SiO}_{2}$ & 55.62 & 55.47 & 56.49 & 55.81 & 54.49 & & 55.53 & 55.08 \\
\hline $\mathrm{Al}_{2} \mathrm{O}_{3}$ & 4.35 & 4.95 & 3.10 & 3.54 & 4.88 & & 5.00 & 3.74 \\
\hline $\mathrm{Cr}_{2} \mathrm{O}_{3}$ & 0.62 & 0.75 & 0.57 & 0.49 & 0.68 & & 0.65 & 0.59 \\
\hline $\mathrm{TiO}_{2}$ & 0.11 & 0.00 & 0.11 & 0.18 & 0.12 & & 0.11 & 0.19 \\
\hline${ }^{\mathrm{a}} \mathrm{FeO}$ & 5.92 & 5.44 & 5.80 & 5.58 & 5.51 & & 5.89 & 6.29 \\
\hline $\mathrm{MgO}$ & 32.69 & 33.13 & 33.80 & 33.06 & 32.88 & & 32.96 & 33.03 \\
\hline $\mathrm{MnO}$ & 0.15 & 0.14 & 0.15 & 0.14 & 0.08 & & 0.23 & 0.16 \\
\hline $\mathrm{NiO}$ & 0.11 & 0.00 & 0.04 & 0.11 & 0.09 & & 0.11 & 0.07 \\
\hline $\mathrm{CaO}$ & 0.59 & 0.61 & 0.77 & 0.60 & 0.62 & & 0.54 & 0.50 \\
\hline $\mathrm{Na}_{2} \mathrm{O}$ & 0.02 & 0.02 & 0.06 & 0.00 & 0.03 & & 0.08 & 0.02 \\
\hline $\mathrm{K}_{2} \mathrm{O}$ & 0.01 & 0.00 & 0.01 & 0.00 & 0.00 & & 0.06 & 0.00 \\
\hline Total & 100.19 & 100.51 & 100.90 & 99.51 & 99.38 & & 101.16 & 99.67 \\
\hline \multicolumn{9}{|l|}{ Spinels } \\
\hline $\mathrm{SiO}_{2}$ & 0.00 & 0.03 & 0.07 & 0.02 & 0.01 & 0.07 & 0.04 & 0.11 \\
\hline $\mathrm{Al}_{2} \mathrm{O}_{3}$ & 44.53 & 52.14 & 42.85 & 46.94 & 44.23 & 51.81 & 45.97 & 49.02 \\
\hline $\mathrm{Cr}_{2} \mathrm{O}_{3}$ & 26.06 & 19.03 & 27.21 & 23.84 & 26.91 & 18.49 & 24.04 & 19.90 \\
\hline $\mathrm{TiO}_{2}$ & 0.17 & 0.07 & 0.09 & 0.21 & 0.30 & 0.03 & 0.11 & 0.17 \\
\hline $\mathrm{FeO}$ & 12.79 & 10.93 & 12.12 & 12.42 & 13.90 & 11.20 & 15.01 & 13.07 \\
\hline${ }^{\mathrm{b}} \mathrm{Fe}_{2} \mathrm{O}_{3}$ & 0.00 & 0.00 & 1.17 & 0.00 & 0.00 & 0.01 & 0.00 & 1.00 \\
\hline $\mathrm{MgO}$ & 17.19 & 18.99 & 17.64 & 17.95 & 16.63 & 19.06 & 16.05 & 17.66 \\
\hline $\mathrm{MnO}$ & 0.11 & 0.09 & 0.18 & 0.16 & 0.15 & 0.14 & 0.23 & 0.15 \\
\hline $\mathrm{NiO}$ & 0.20 & 0.12 & 0.17 & 0.21 & 0.21 & 0.25 & 0.20 & 0.15 \\
\hline $\mathrm{CaO}$ & 0.03 & 0.00 & 0.01 & 0.00 & 0.01 & 0.05 & 0.01 & 0.05 \\
\hline Total & $\overline{101.08}$ & $\overline{101.40}$ & $\overline{101.51}$ & $\overline{101.75}$ & $\overline{102.35}$ & $\overline{101.11}$ & $\overline{101.66}$ & $\overline{101.28}$ \\
\hline
\end{tabular}

Total $\mathrm{Fe}$ as FeO.

${ }^{\mathrm{b}}$ By stoichiometry.

impossible to distinguish between the olivines from the other study areas.

\section{$\mathrm{Mg} /(\mathrm{Mg}+\mathrm{Fe})$ vs. $\mathrm{Cr} /(\mathrm{Cr}+\mathrm{Al})$ in Pyroxenes and Spinel (Fig. 5)}

Partial melting of peridotites increases the $\mathrm{Mg} /(\mathrm{Mg}+\mathrm{Fe})$ and $\mathrm{Cr} /(\mathrm{Cr}+\mathrm{Al})$ ratios in pyroxenes of the residual solid. In natural peridotites, however, the $\mathrm{Mg} /(\mathrm{Mg}+\mathrm{Fe})$ ratio decreases in the residual spinel as iron enters the chromite molecule (Irvine, 1965, 1967; Dick, 1977; Dick and Fisher, 1984).

Pyroxenes and spinel from peridotites of the Galicia margin have compositions very close to those observed in the plagioclase-bearing Ronda body. These compositions are far less depleted than those from northern Oman and New Caledonia harzburgites that are related to ophiolite (i.e., oceanic crust) generation. Two points are especially noteworthy: (1) the minerals from the harzburgite at Santa Elena appear poorly depleted and probably have not experienced extensive partial melting and (2) the minerals from the western Pyrenean lherzolites have rather fertile compositions, which suggests that the rocks experienced very limited partial melting or none at all.
Nevertheless, partial melting is not the only process responsible for the mineral compositional changes shown in Figure 5. The effect of plagioclase crystallization from pyroxenes and spinel must also be taken into consideration. At relatively high temperatures, the reaction produces the same result as the partial-melting process: increasing the concentrations of $\mathrm{Mg}$ and $\mathrm{Cr}$ in pyroxenes relative to $\mathrm{Fe}$ and $\mathrm{Al}$ and increasing the concentrations of $\mathrm{Fe}$ and $\mathrm{Cr}$ in spinel. The result is probably slightly different at moderate temperatures when $\mathrm{Cr}$ and $\mathrm{Al}$ do not enter significantly into the pyroxene crystal lattices. Superposition of the effect of the mineral facies change upon the effect of partial melting can also account for the relatively depleted compositions of minerals in plagioclase-bearing rocks (Galicia margin and Ronda Massif) in comparison to plagioclase-free peridotites (Santa Elena harzburgite and Saraillhé lherzolite).

Special attention is due to the composition of minerals from the Lizard peridotite. In each diagram in Figure 5, the compositions of the minerals of the Lizard peridotite plot in a separate field and appear much richer in iron than any of the other samples. This suggests that this peridotite represents an ultramafic igneous cumulate (Rothstein, 1971), rather than a residual man- 
Table 3. Selected analyses of minerals in clinopyroxenes, orthopyroxenes, and spinels from the various ultramafic bodies described in this paper. Electron microprobe CAMEBAX (Centre de Mesures Physiques, Université de Clermont II). Acceleration voltage $=15 \mathrm{kV}$; current $=11$ nA; counting time = 30 sec. $R 1=$ Ronda, Spain (plagioclase-free); R2 $=$ Ronda, Spain (plagioclase-rich); L = Lizard Point, Cornwall, United Kingdom; $\mathbf{S}=$ Saraillhé, western Pyrenees; SE = Santa Elena, Costa Rica; NO = northern Oman (Augé, 1983; counting time 6 sec.); HU = Humboldt Massif, New Caledonia (Podvin, 1983; counting time variable).

\begin{tabular}{|c|c|c|c|c|c|c|c|}
\hline Mineral & R1 & R2 & L & $\mathrm{S}$ & $\mathrm{SE}$ & NO & HU \\
\hline \multicolumn{8}{|c|}{ Clinopyroxenes } \\
\hline $\mathrm{SiO}_{2}$ & 51.41 & 51.33 & 49.21 & 51.90 & 53.20 & 54.14 & \\
\hline $\mathrm{Al}_{2} \mathrm{O}_{3}$ & 6.72 & 4.45 & 8.54 & 7.42 & 4.50 & 0.94 & \\
\hline $\mathrm{Cr}_{2} \mathrm{O}_{3}$ & 0.98 & 1.31 & 0.88 & 0.65 & 0.93 & 0.51 & \\
\hline $\mathrm{TiO}_{2}$ & 0.36 & 0.96 & 0.59 & 0.56 & 0.00 & 0.00 & \\
\hline${ }^{\mathrm{a}} \mathrm{FeO}$ & 2.29 & 2.37 & 3.59 & 2.64 & 2.19 & 1.90 & \\
\hline $\mathrm{MgO}$ & 14.49 & 15.76 & 14.31 & 13.69 & 16.41 & 18.14 & \\
\hline $\mathrm{MnO}$ & 0.09 & 0.12 & 0.03 & 0.10 & 0.08 & 0.02 & \\
\hline $\mathrm{NiO}$ & 0.06 & 0.03 & 0.03 & 0.12 & 0.00 & 0.00 & \\
\hline $\mathrm{CaO}$ & 21.66 & 23.10 & 21.84 & 21.31 & 23.20 & 23.59 & \\
\hline $\mathrm{Na}_{2} \mathrm{O}$ & 1.32 & 0.54 & 0.48 & 1.70 & 0.49 & 0.04 & \\
\hline $\mathrm{K}_{2} \overline{\mathrm{O}}$ & 0.00 & 0.00 & 0.00 & 0.00 & 0.00 & 0.00 & \\
\hline Total & 99.38 & 99.97 & 99.50 & 100.09 & 101.00 & 99.28 & \\
\hline \multicolumn{8}{|c|}{ Orthopyroxenes } \\
\hline $\mathrm{SiO}_{2}$ & 54.14 & 56.79 & 52.73 & 55.53 & 56.21 & 57.24 & 57.59 \\
\hline $\mathrm{Al}_{2} \mathrm{O}_{3}$ & 5.41 & 2.25 & 6.59 & 4.38 & 4.52 & 0.86 & 0.89 \\
\hline $\mathrm{Cr}_{2} \mathrm{O}_{3}$ & 0.66 & 0.53 & 0.64 & 0.29 & 0.54 & 0.36 & 0.52 \\
\hline $\mathrm{TiO}_{2}$ & 0.14 & 0.26 & 0.31 & 0.12 & 0.00 & 0.00 & 0.00 \\
\hline${ }^{\mathrm{a}} \mathrm{FeO}$ & 5.90 & 6.08 & 6.70 & 7.05 & 5.86 & 5.64 & 5.34 \\
\hline $\mathrm{MgO}$ & 32.45 & 33.92 & 31.07 & 32.76 & 32.75 & 34.75 & 34.13 \\
\hline $\mathrm{MnO}$ & 0.22 & 0.16 & 0.14 & 0.22 & 0.09 & 0.18 & 0.14 \\
\hline $\mathrm{NiO}$ & 0.08 & 0.07 & 0.27 & 0.09 & 0.00 & 0.00 & 0.08 \\
\hline $\mathrm{CaO}$ & 0.53 & 0.61 & 1.46 & 0.48 & 1.17 & 0.53 & 1.44 \\
\hline $\mathrm{Na}_{2} \mathrm{O}$ & 0.00 & 0.04 & 0.01 & 0.03 & 0.00 & 0.00 & 0.00 \\
\hline $\mathrm{K}_{2} \mathrm{O}$ & 0.00 & 0.00 & 0.00 & 0.01 & 0.00 & 0.01 & 0.00 \\
\hline Total & 99.53 & $\overline{100.71}$ & 99.92 & 100.96 & $\overline{101.14}$ & 99.57 & 100.13 \\
\hline \multicolumn{8}{|l|}{ Spinels } \\
\hline $\mathrm{SiO}_{2}$ & 0.04 & 0.05 & 0.07 & 0.04 & 0.00 & 0.09 & 0.07 \\
\hline $\mathrm{Al}_{2} \mathrm{O}_{3}$ & 51.65 & 37.66 & 36.43 & 61.65 & 50.67 & 24.30 & 10.17 \\
\hline $\mathrm{Cr}_{2} \mathrm{O}_{3}$ & 17.65 & 29.97 & 32.41 & 6.46 & 19.22 & 42.98 & 58.04 \\
\hline $\mathrm{TiO}_{2}$ & 0.18 & 0.22 & 0.09 & 0.06 & 0.08 & 0.00 & 0.01 \\
\hline $\mathrm{FeO}$ & 12.54 & 15.61 & 16.99 & 11.62 & 12.18 & 16.91 & 18.65 \\
\hline${ }^{b} \mathrm{Fe}_{2} \mathrm{O}_{3}$ & 0.12 & 2.03 & 0.80 & 0.00 & 0.17 & 3.70 & 3.21 \\
\hline $\mathrm{MgO}$ & 18.17 & 14.69 & 13.60 & 19.47 & 18.42 & 12.30 & 9.54 \\
\hline $\mathrm{MnO}$ & 0.19 & 0.23 & 0.28 & 0.06 & 0.00 & 0.28 & 0.33 \\
\hline $\mathrm{NiO}$ & 0.16 & 0.13 & 0.05 & 0.33 & 0.30 & 0.16 & 0.05 \\
\hline $\mathrm{CaO}$ & 0.02 & 0.08 & 0.13 & 0.00 & 0.04 & 0.02 & 0.00 \\
\hline Total & $\overline{100.72}$ & $\overline{100.70}$ & $\overline{100.85}$ & 99.69 & $\overline{101.08}$ & $\overline{100.74}$ & 100.07 \\
\hline
\end{tabular}

${ }^{a}$ Total $\mathrm{Fe}$ and $\mathrm{FeO}$.

${ }^{b}$ By stoichiometry.

tle tectonite from an ophiolite (Kirby, 1979). Nevertheless, the high iron content is rare even in ophiolitic ultramafic cumulates. The Lizard peridotites appear to be cumulates from a highly differentiated tholeiitic melt, as is also suggested by the abundance of orthopyroxene, a rather uncommon phase in ophiolitic cumulates. As an example, the iron- and chromium-rich spinel from the Lizard peridotite is compared with spinel of metamorphic cumulate xenoliths from Eggéré (Algeria; Kornprobst et al., 1987b) in which two different units can be distinguished on the basis of the $\mathrm{Mg} /(\mathrm{Mg}+\mathrm{Fe})$ ratio (Fig. 5D).

\section{Consideration of Titanium}

In Figure 5, the effects of partial melting and mineral facies change are superimposed. As already discussed by Libourel (1985), taking $\mathrm{Ti}$ into consideration would theoretically allow discrimination between the two processes. Spinel and clinopyroxene compositions give reliable information on these processes.

\section{$\mathrm{Mg} /(\mathrm{Mg}+\mathrm{Fe})$ vs. Ti in Spinel}

The spinel from the harzburgites is shown in Figure 6A to be especially low in $\mathrm{Ti}$, as is the spinel from the plagioclase-free lherzolite at Saraillhé. However, the spinel from the other samples displays increasing $\mathrm{Ti}$ concentrations as the $\mathrm{Mg} /(\mathrm{Mg}+\mathrm{Fe})$ ratios decrease. This signifies that the major event experienced by the latter minerals was a change in mineral facies, rather than partial melting. Relatively high $\mathrm{Mg} /(\mathrm{Mg}+\mathrm{Fe})$ ratios in spinels from Saraillhé and Santa Elena characterize the lack of plagioclase in the rocks and support a relatively small amount of partial melting at Santa Elena. The $\mathrm{Cr} /(\mathrm{Cr}+\mathrm{Al})$ vs. Ti diagram in spinel also distinguishes the various ultramafic populations (Fig. 6B).

\section{$\mathrm{Mg} /(\mathrm{Mg}+\mathrm{Fe})$ vs. Ti in Clinopyroxene}

At first glance, the data shown in Figure 6C appear to be indiscriminate. The clinopyroxene from Saraillhé displays a rela- 


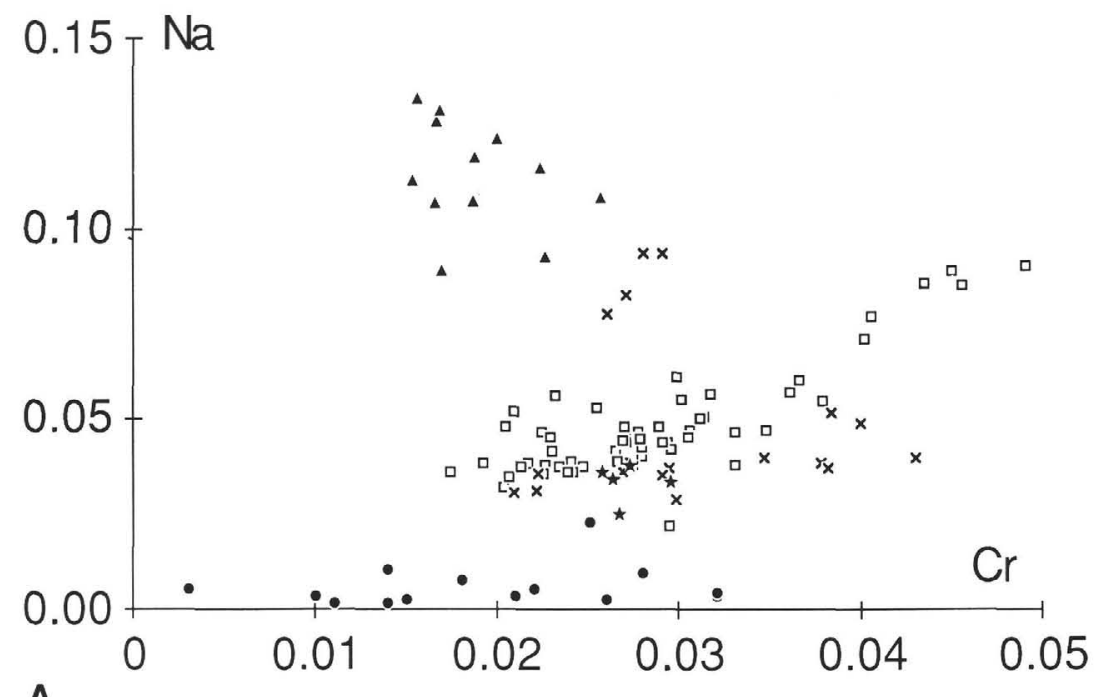

A

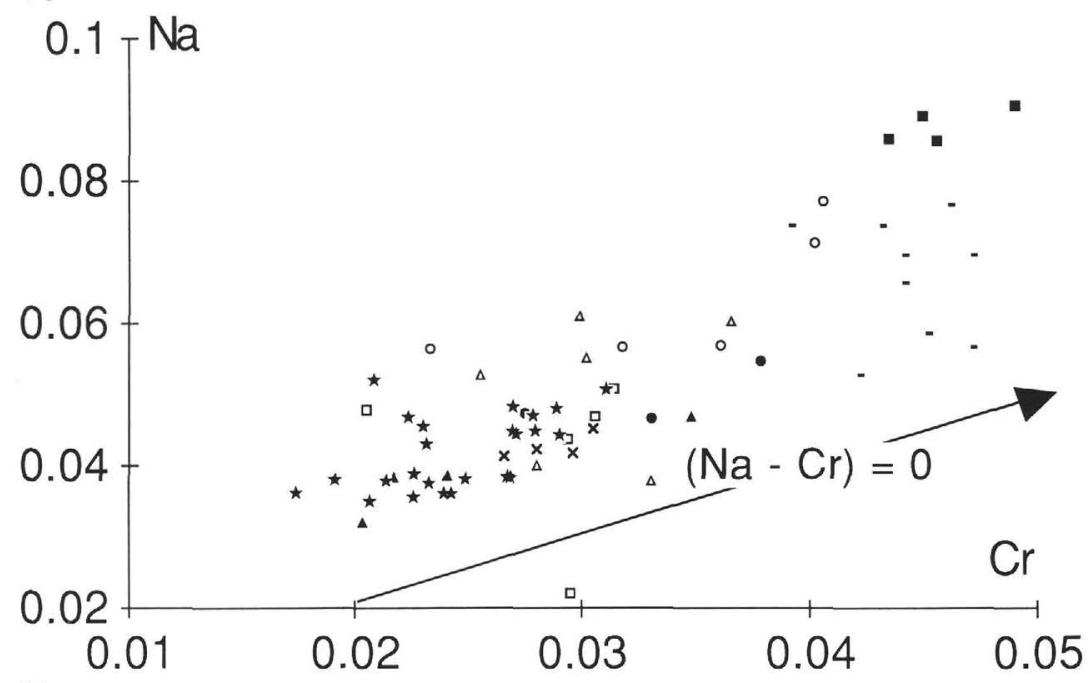

B

Figure 2. Cr vs. Na in clinopyroxene (per formula on 6 oxygens). A. Comparison of peridotites from Galicia margin and other low-pressure ultramafic bodies. Open squares = Galicia; solid dots = northern Oman (Augé, 1983); solid squares = Lizard; crosses = Ronda; solid triangles = western Pyrenees; stars = Santa Elena. B. Galicia margin peridotite samples. Sample identifications are given in Table 1. Solid dots $=$ G4; open circles $=\mathrm{G} 8$; solid squares $=\mathrm{G} 11$; open squares $=\mathrm{G} 12$; solid triangles $=\mathrm{G} 13$; open triangles $=\mathrm{G} 14$; crosses = G16; stars = G19; bars = H78D24 (Boillot et al., 1980).

tively constant concentration of $\mathrm{Ti}$. The minerals from Galicia and Ronda are either richer or poorer with respect to Ti concentration over a relatively small range of $\mathrm{Mg} /(\mathrm{Mg}+\mathrm{Fe})$ ratios. As expected, the clinopyroxenes from the harzburgites related to ophiolites have a very low $\mathrm{Ti}$ content. The plotted dispersion of the clinopyroxenes from Galicia and Ronda suggests that they experienced both a mineral facies change and a minor amount of partial melting. This is well known at Ronda on the basis of petrological and geochemical studies (Dickey, 1970; Didon et al., 1973; Frey et al., 1985) and is likely also the case for the Galicia margin samples.

\section{(Na-Cr) vs. Ti in Clinopyroxene}

The two components $((\mathrm{Na}-\mathrm{Cr})=$ jadeite $)$ and $\mathrm{Ti}$ are incompatible and move into the liquid during partial melting (part of the elemental $\mathrm{Na}$ is kept in the clinopyroxene to form the more refractory kosmochlor molecule $\mathrm{NaCrSi}_{2} \mathrm{O}_{6}$ ). The secondary crystallization of plagioclase also decreases the jadeite content of clinopyroxene, whereas $\mathrm{Ti}$ is concentrated in that clinopyroxene. Taking the clinopyroxene of Saraillhé as an example for poorly depleted plagioclase-free peridotite (see the preceding), the behavior of $(\mathrm{Na}-\mathrm{Cr})$ and $\mathrm{Ti}$ in clinopyroxene during the partialmelting event is exemplified by the trend from the Saraillhé to Santa Elena and northern Oman minerals (Fig. 7A), which is toward the negative values of $(\mathrm{Na}-\mathrm{Cr}$ ) (corresponding to the calculation of the pseudoureyite molecule in clinopyroxene). In the same way, the main effect of the mineral facies change is exemplified by the trend between the least and the most recrystallized Ronda samples in the plagioclase field (even if a minor partialmelting event must also be taken into consideration). The clinopyroxenes from the Galicia margin peridotites are greatly dispersed between the two trends (Fig. 7B); as in the previous section, this is interpreted as the result of the additive effects of both the limited partial melting and recrystallization processes in the plagioclase field. Nevertheless, in considering each sample separately (Fig. 7 C), the plots appear much more gathered in 

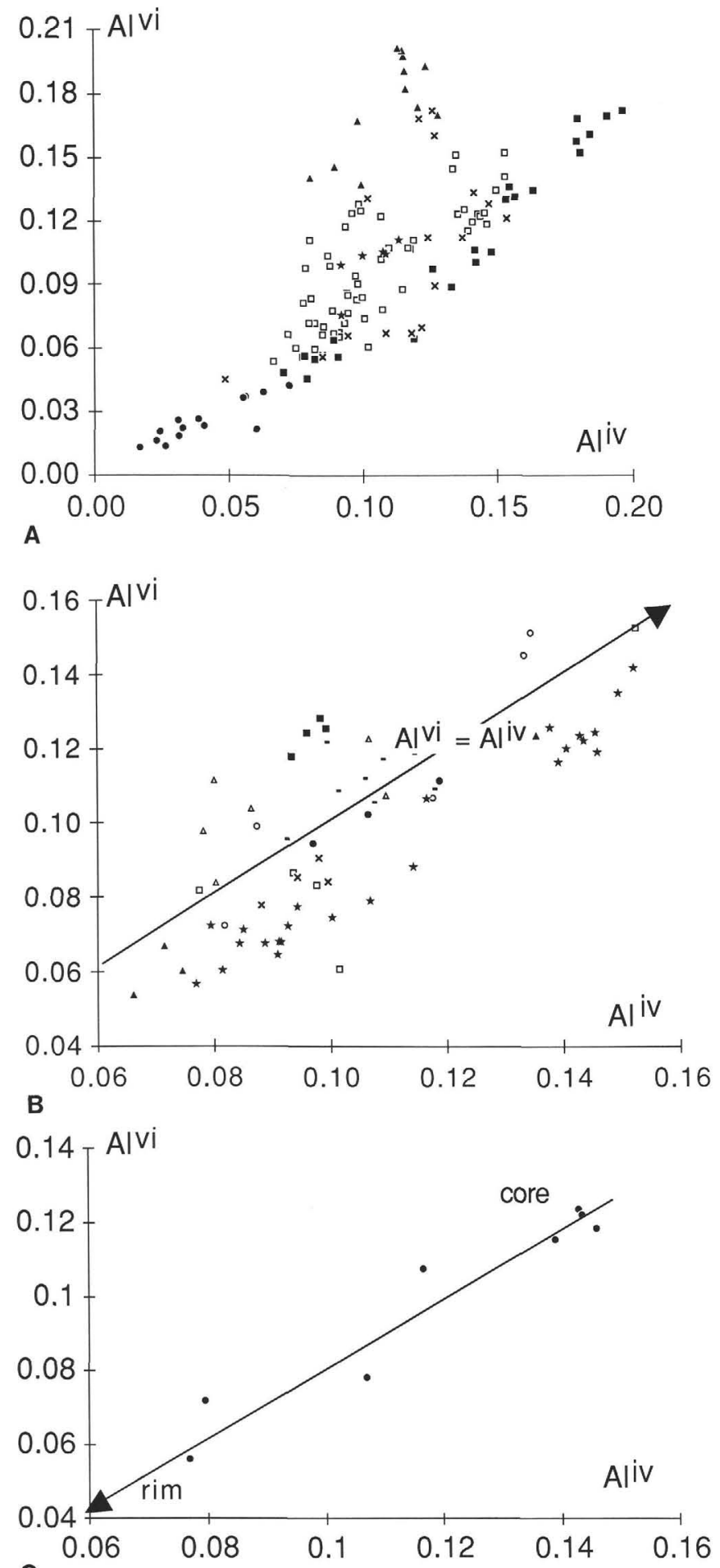

\section{C}

Figure 3. $\mathrm{Al}^{\mathrm{iv}}$ vs. $\mathrm{Al}^{\mathrm{vi}}$ in clinopyroxene. A. Comparison of Galicia margin peridotites to those from other low-pressure ultramafic bodies. Open squares $=$ Galicia; solid dots $=$ northern Oman (Augé, 1983); solid squares = Lizard; crosses = Ronda; solid triangles = western Pyrenees; stars = Santa Elena. B. Galicia margin peridotite samples. Sample identifications are given in Table 1 . Solid dots $=\mathrm{G} 4$; open circles $=$ G8; solid squares $=\mathrm{G} 11$; open squares $=\mathrm{G} 12$; solid triangles $=\mathrm{G} 13$; open triangles = G14; crosses = G16; stars = G19; bars = H78D24 (Boillot et al., 1980). C. Variation in $\mathrm{Al}$ concentration from core to rim in a single clinopyroxene phenoclast from Galicia (G19).

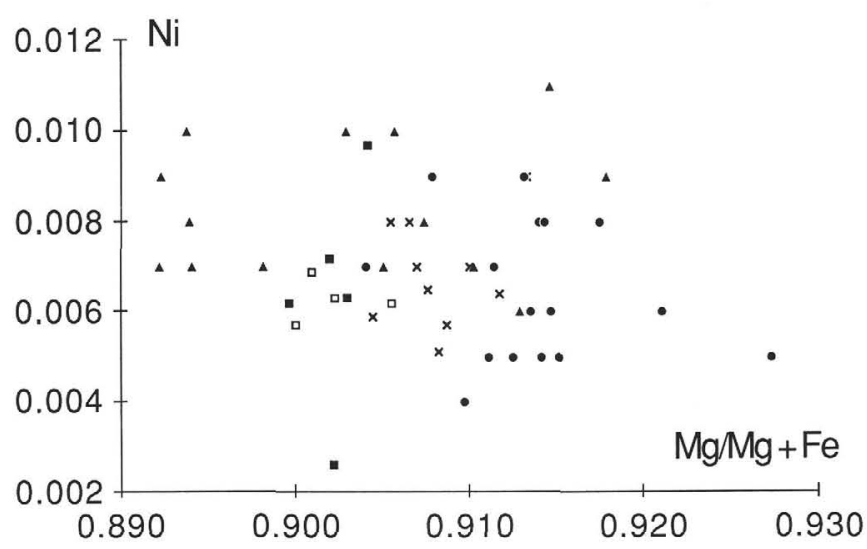

Figure 4. $\mathrm{Mg} /(\mathrm{Mg}+\mathrm{Fe})$ vs. $\mathrm{Ni}$ in olivine. Comparison of Galicia margin peridotites to those from other low-pressure ultramafic bodies. Open squares = Galicia; solid dots = northern Oman (Augé, 1983); solid squares $=$ Lizard; crosses $=$ Ronda; solid triangles $=$ western Pyrenees; stars = Santa Elena.

the diagram. This suggests that the ultramafic body from the Galicia margin experienced heterogeneous recrystallization in the plagioclase field, probably after a heterogeneous partialmelting event of small extent.

\section{ZONING OF THE PHENOCLASTS: PRELIMINARY DATA}

Significant compositional variations occur across single phenoclasts in the ultramafic rocks. An especially accurate report of such variations (Obata, 1980) concerned Al behavior in an orthopyroxene phenoclast from the Ronda Massif. Compositional variations from the core to the margin of phenoclasts and from phenoclast to neoblast were studied in Pyrenean lherzolites (Conquéré and Fabriés, 1984a, 1984b). As for metamorphic rocks, zoning patterns can be used to characterize prograde and retrograde pressure-temperature crystallization paths. Nevertheless, as most ultramafic rocks experienced a single evolutionary event from mantle conditions to lower pressures and temperatures, only retrograde effects are generally visible as clues to characterize the stages of ultramafic body ascent (Conquéré and Fabriés, $1984 a, 1984 b)$. More or less marked deformation speeds up the retrograde recrystallization by decreasing the size of the grains and increasing the defect density in the crystal lattice (Nicolas and Poirier, 1976); considering only the poorly deformed areas of the phenoclasts, cation diffusion across the crystal lattice appears to be the main mechanism to account for zoning. In this case, achieving equilibrium is a matter of temperature, grain size, and time (Crank, 1975). Controlling the variables of temperature and grain size allows calculation of the rate of ascent (Lasaga, 1983). Ozawa (1984) distinguished between slow- and fast-cooling ultramafic rocks (ophiolitic bodies and xenoliths in basalt, respectively) on the basis of the distribution of $\mathrm{Fe}$ and $\mathrm{Mg}$ between olivine and spinel crystals of different sizes in peridotites. In this work, a comparison of zoning patterns in the phenoclasts from the Galicia margin peridotite with other occurrences is attempted to determine the order of magnitude of their cooling or emplacement times. For this purpose, especially slow-diffusing cations such as $\mathrm{Al}$ and $\mathrm{Cr}$ are considered.

\section{Clinopyroxene Zoning}

The behavior of $\Sigma \mathrm{Al}$ across individual clinopyroxene phenoclasts was compared in peridotites from the Galicia margin, Ronda Massif, and Costa Rica. The re-equilibration pattern 

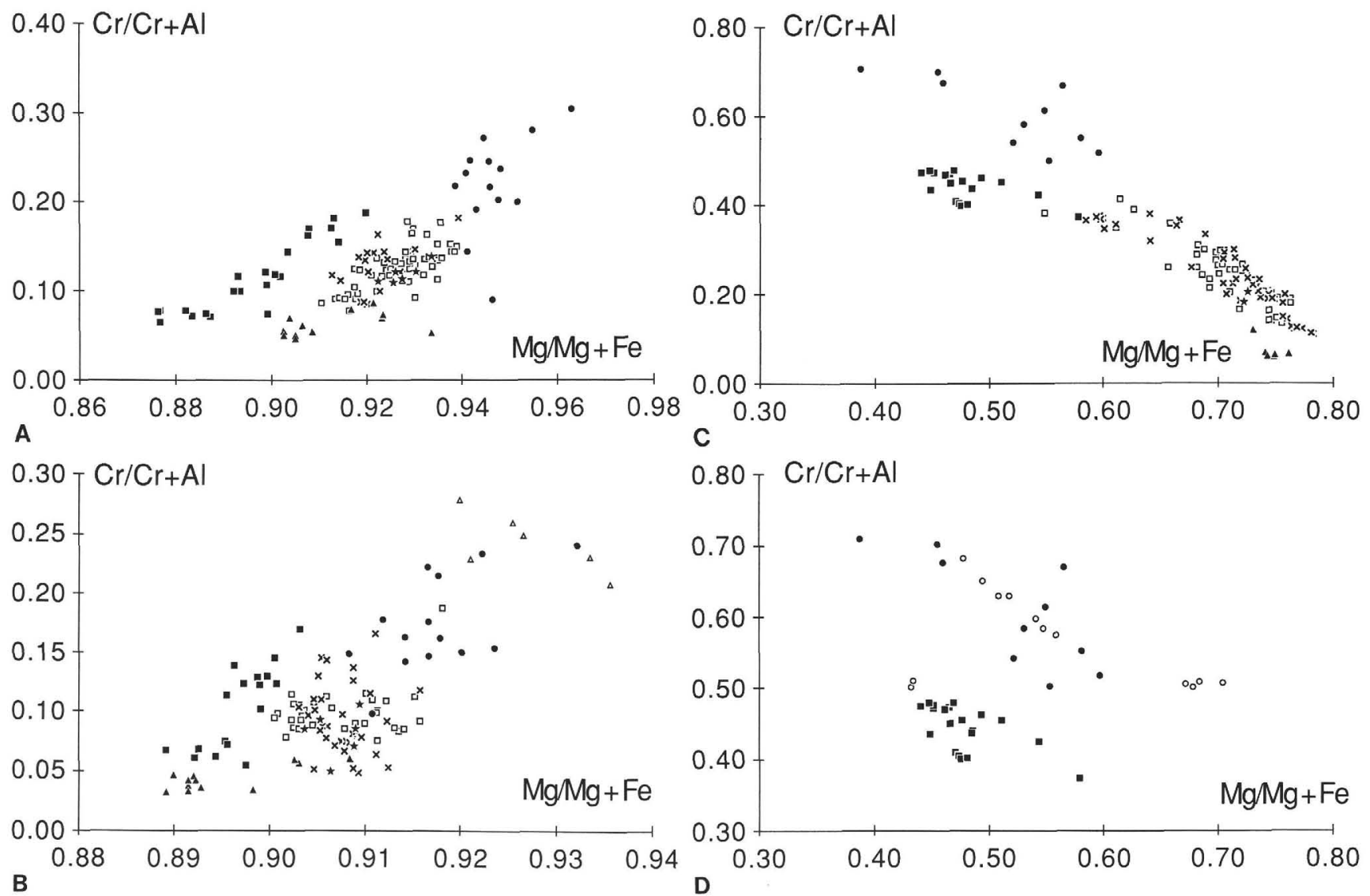

Figure $5 . \mathrm{Mg} /(\mathrm{Mg}+\mathrm{Fe})$ vs. $\mathrm{Cr} /(\mathrm{Cr}+\mathrm{Al})$. Comparison of Galicia margin peridotites to those from other low-pressure ultramafic bodies. Open squares = Galicia; solid dots = northern Oman (Augé, 1983); solid squares = Lizard; crosses = Ronda; solid triangles = western Pyrenees; stars = Santa Elena; open triangles = New Caledonia (Podvin, 1983). A. In clinopyroxene. B. In orthopyroxene. C. In spinel. D. Comparison of spinel from Lizard peridotite (solid squares), from northern Oman harzburgite (solid dots), and from $\mathrm{Mg}$ - and Fe-rich spinel from Eggéré ultramafic cumulates (open circles; Kornprobst et al., 1987b).

from core to margin appears especially marked in the Galicia margin samples; it involves a 150 - $\mu$ m-thick rim across which $\Sigma \mathrm{Al}$ continuously decreases to the margin (Fig. 8A). The Ronda crystal also exhibits a strong concentration variation across a narrow rim (about $40 \mu \mathrm{m}$ ). These patterns signify that both rocks experienced relatively strong pressure and temperature changes after equilibration in the plagioclase field $(\Sigma \mathrm{Al} \sim 0.25)$, but the reequilibration stage was significantly longer for the Galicia margin sample. Taking dt/ $\mathrm{r}^{2} \sim 1$ (in which $t$ represents time and $r$ the radius of a re-equilibrated crystal; Crank, 1975), the Ronda re-equilibration features developed about 14 times faster than those of the Galicia margin sample ( 3 and 42 m.y., respectively, by using the diffusion coefficient for $\mathrm{Al}$ in clinopyroxene at $1200^{\circ} \mathrm{C}$, as proposed by Freer et al., 1982). Compared to the Ronda and Galicia samples, the harzburgite at Santa Elena has clinopyroxene crystals with very weak variations in the concentration of $\mathrm{Al}$ from core to margin (Fig. 8B); this suggests relatively fast cooling and cold tectonic emplacement, as already demonstrated for ophiolitic ultramafic cumulates (Ernewein, 1987).

\section{Orthopyroxene Zoning}

The behavior of $\Sigma \mathrm{Al}$ in orthopyroxene phenoclasts from the Galicia margin and Ronda peridotites is very similar to that in clinopyroxene (Figs. 9A and 9B). In the samples from the Ronda body, $\Sigma \mathrm{Al}$ concentrations decrease at about $90 \mu \mathrm{m}$ from the crystal margin, as compared to about $340 \mu \mathrm{m}$ in orthopyroxene from Galicia margin. As calculated previously for clinopyrox- ene, re-equilibration was again about 14 times faster at Ronda than at Galicia, at a constant temperature. An orthopyroxene phenoclast from the western Pyrenees also shows a relatively narrow re-equilibration margin (about $110 \mu \mathrm{m}$ ), which would indicate much faster emplacement than the Galicia peridotites underwent (Fig. 9C); nevertheless, it is not appropriate to strictly compare one rock to the other because they underwent recrystallization in different mineral facies. An additional comparison was made with an orthopyroxene phenoclast from an ultramafic xenolith at Tallante (Andalusia, Spain; Fig. 9D); the re-equilibration margin of that phenoclast is less than $20 \mu \mathrm{m}$. This observance signifies that the re-equilibration preceded at least 300 times faster than at the Galicia margin (or at much higher temperatures). In this particular case, decreasing concentrations of $\Sigma \mathrm{Al}$ are related to increasing temperature because the $\mathrm{Cr}$ concentration increases toward the margin of the crystal (Tabit, 1986).

\section{Spinel Zoning}

The behavior of $\mathrm{Cr}$ and $\mathrm{Al}$ across spinel phenoclasts from the Galicia margin and Ronda Massif is not as significant as in pyroxenes. In both cases, the re-equilibration margins are about $100 \mu \mathrm{m}$ thick, although they have different shapes (Figs. 10A10C). The Ronda spinel core might have retained zoning from a high-pressure mineral facies. On the other hand, some crystals from the Galicia margin show very "flat" zoning patterns (Fig. 10D), with either relatively high or relatively low $\mathrm{Cr}$ concentrations. This behavior could be related to heterogeneous partial 

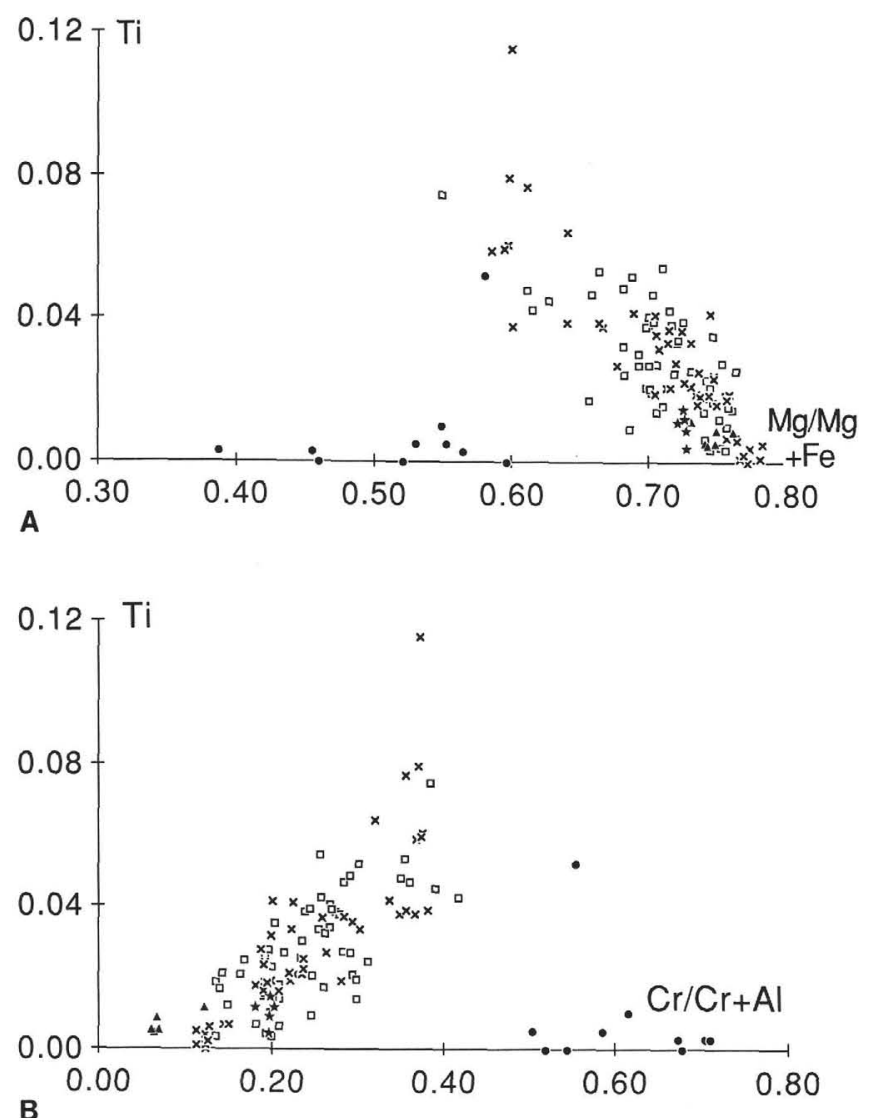

B

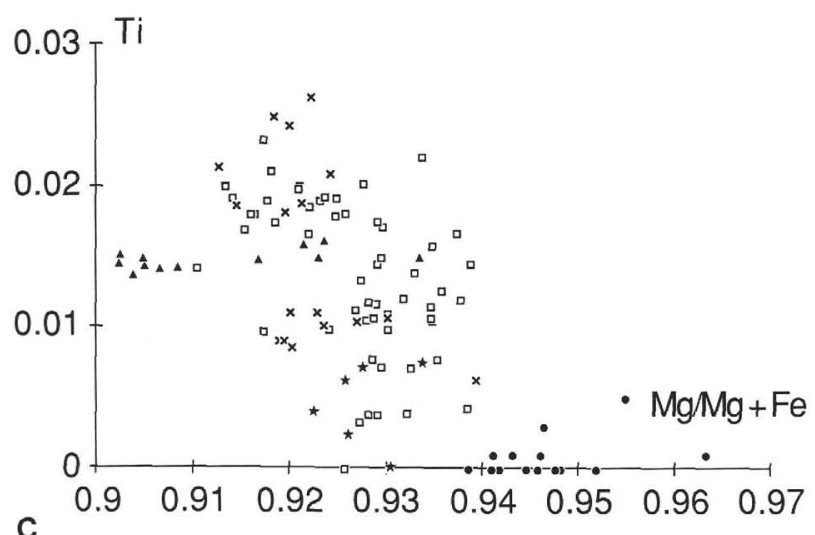

Figure 6. Behavior of Ti. Comparison of Galicia margin peridotite to peridotites from other low-pressure ultramafic bodies. Open squares = Galicia; solid dots = northern Oman (Augé, 1983); solid squares = Lizard; crosses = Ronda; solid triangles = western Pyrenees; stars = Santa Elena. A. $\mathrm{Mg} /(\mathrm{Mg}+\mathrm{Fe})$ vs. $\mathrm{Ti}$ in spinel. B. $\mathrm{C} /(\mathrm{Cr}+\mathrm{Al})$ vs. $\mathrm{Ti}$ in spinel. C. $\mathrm{Mg} /(\mathrm{Mg}+\mathrm{Fe})$ vs. $\mathrm{Ti}$ in clinopyroxene.

melting and recrystallization features (see the preceding discussion).

Although interpretation is difficult at this time, the spinel zoning gives some reliable information: (1) spinel from Santa Elena has a very flat pattern that can be related to fast cooling (Fig. 11) and (2) spinel from Lizard shows a very unusual zonation with bell-shaped $\mathrm{Fe}^{3+}$ zoning (Fig. 12A) and oscillatory zoning for $\mathrm{Cr}, \mathrm{Al}, \mathrm{Fe}$, and $\mathrm{Mg}$ (Figs. $12 \mathrm{~B}$ and $12 \mathrm{C}$ ). This behav- ior can be related to magmatic crystallization or to superimposition of magmatic and solid-state events.

\section{CONCLUSIONS}

The following points are emphasized from the preceding discussion:

1. The plagioclase-bearing ultramafic tectonites from the Galicia margin have mineral compositions similar to the minerals from the Ronda Massif. These compositions were achieved after minor partial melting and the transition from the spinel to the plagioclase-bearing facies fields. They clearly differ from the depleted compositions of the minerals of harzburgites related to ophiolites. Thus, the peridotites from the Galicia margin probably do not represent the oceanic lithosphere of the Atlantic Ocean.

2. Although the Ronda plagioclase peridotites exhibit relict mineral compositions equilibrated under relatively high pressures, the peridotites from Galicia margin were fully recrystallized in the plagioclase field. The latter ultramafic body experienced slow recrystallization, at a rate about 14 times slower than that experienced by the assemblages at Ronda. The western Pyrenean lherzolites equilibrated at relatively high pressures (Seiland subfacies); they exhibit relatively fast recrystallization features, suggesting relatively fast (or cold) emplacement in their present geological environment.

These arguments suggest that the ultramafic ridge of the $\mathrm{Ga}$ licia margin drilled during Leg 103 is a piece of deep subcontinental lithospheric upper mantle. This unit could have been emplaced by slow and moderate uplift related to the lithospheric thinning that occurred during the rifting stage. The heat conduction and moderate drop in pressure related to thinning could have limited the extent of partial melting experienced by the rocks. A tectonic denudation of the mantle, as has been suggested by previous studies (Boillot et al., 1980, 1985) and follows, for instance, the model by Wernicke (1985), could have played an important role during the process of ascent of the peridotites toward the surface. Such slow emplacement behavior differs from the fast emplacement suggested by the recrystallization features at Ronda and the western Pyrenees, which probably underwent diapiric emplacement from the asthenosphere along transcurrent faults related to the opening of the Atlantic (Fig. 13; Kornprobst and Vielzeuf, 1984). Note that, according to their relatively older age (Middle Jurassic or older) suggested by Fortané et al. (1986), the emplacement of the peridotites in the Pyrenees was not necessary synchronous with the emplacement of the ultramafic bodies in the Gibraltar area. The structural relationships between these different ultramafic units are schematically expressed in Figure 14.

\section{ACKNOWLEDGMENTS}

The study (field observations, sampling, and probe analyses) was supported by the ATP "Geodynamique," "Transferts," and "Geologie et Géophysique des Océans" of CNRS and INSU. We thank G. Boillot, C. A. Evans, and J. Girardeau for giving us the opportunity to work on Leg 103 samples. The authors are grateful to P. Boivin, A. Bonneville, A. Boumehdi, J. Clemens, G. Libourel, A. Provost, and D. Vielzeuf for help provided during the ripening of the paper. We are also endebted to A. Meyer, A. Macdonald, and D. Elthon for a number of pertinent corrections and suggestions, as well as for an extremely careful polishing of the writing.

\section{REFERENCES}

Aubouin, J., Mattauer, M., and Allègre, C. J., 1977. La couronne ophiolitique périaustralienne: un charriage océanique représentatif des stades précoces de l'évolution alpine. C. R. Acad. Sci. Ser. 2, 285:953-956. 
Augé, T., 1983. Etude minéralogique et pétrographique de roches basiques et ultrabasiques du complexe ophiolitique du nord Oman. Doc. B.R.G.M., 65.

Boillot, G., 1986. Comparison between the Galicia and Aquitaine margins. Tectonophysics, 129:243-255.

Boillot, G., Grimaud, S., Mauffret, A., Mougenot, D., Kornprobst, J. Mergoil-Daniel, J., and Torrent, G., 1980. Ocean-continent boundary of the Iberian Margin: a serpentinite diapir west off the Galicia Bank. Earth Planet. Sci. Lett., 48:23-34.

Boillot, G., Winterer, E. L., Meyer, A., Applegate, J., Baltuck, M., Bergen, J. A., Comas, M. C., Davies, T. A., Dunham, K., Evans, C. A., Girardeau, J., Goldberg, D., Haggerty, J., Jansa, L. F., Johnson, J. A., Kasahara, J., Loreau, J.-P., Luna-Sierra, E., Moullade, M., Ogg, J., Sarti, M., Thurow, J., and Williamson, A. W., 1985. Résultats préliminaires de la campagne 103 du Joides Resolution (ODP) au marge de la Galice (Espagne): sédimentation et distension pendant le "rifting" d'une marge stable; hypothèse d'une dénudation tectonique du manteau supérieur. C. R. Acad. Sci. Ser. 2, 301: 627-632.

Boudier, F., and Coleman, R. G., 1981. Cross section through the peridotite in the Samail Ophiolite, southeastern Oman Mountains. $J$. Geophys. Res., 86(B4):2573-2592.

Coleman, R. G., 1977. Ophiolites: Berlin (Springer-Verlag).

Conquéré, F., 1977a. Pétrologie des pyroxénites litées dans les complexes ultramafiques de l'Ariège (France) et autres gisements de lherzolites à spinelle. I-Compositions minéralogiques et chimiques, évolution des conditions d'équilibre des pyroxénites. Bull. Mineral., 100:42-82.

1977b. Pétrologie des pyroxénites litées dans les complexes ultramafiques de l'Ariège (France) et autres gisements de lherzolites à spinelle. II-Pétrogenèse: une discussion. Bull. Mineral., 100:123137.

Conquéré, F., and Fabriès, J., 1984a. Caractères pétrographiques et chimiques des péridotites à spinelle des gisements ultramafiques de Lherz et de Freychinède (Ariège, Pyrénées françaises). In Kornprobst, J. (Ed.), Kimberlites III: Documents: Ann. Sci. Univ. Clermont Ferrand $2,74: 55-83$.

1984b. Chemical disequilibrium and its thermal significance in spinel-peridotites from the Lherz and Freychinède ultramafic bodies (Ariège, French Pyrenees). In Kornprobst, J. (Ed.), Kimberlites II: Amsterdam (Elsevier), 319-331.

Crank, J., 1975. The Mathematics of Diffusion (2nd ed.): Oxford (Oxford Univ. Press).

Darot, M., 1973. Méthodes d'analyse structurale et cinématique. Application a l'étude du massif ultrabasique de la Sierra Bermeja [Thesis]. Univ. de Nantes.

Dick, H.J.B., 1977. Partial melting in the Josephine peridotite. The effect of mineral composition and its consequence for geothermometry and geobarometry. Am. J. Sci., 277:760-801.

Dick, H.J.B., and Fisher, R. L., 1984. Mineralogic studies of the residues of mantle melting: abyssal and alpine type peridotites. In Kornprobst, J. (Ed.), Kimberlites II: Amsterdam (Elsevier), 295-308.

Dickey, J. S., Jr., 1970. Partial fusion products in Alpine-type peridotites: Serrania de la Ronda and other examples. Min. Soc. Am. Spec. Pap., 3:33-49.

Didon, J., Durand-Delga, M., and Kornprobst, J., 1973. Homologies géologiques entre les deux rives du Détroit de Gibraltar. Bull. Soc. Geol. Fr., 15:77-101.

Ernewein, M., 1987. Histoire magmatique d'un segment de croûte océanique téthysienne: pétrologie de la séquence plutonique du Massif ophiolitique de Salahi (Nappe de Semail, Oman) [Thesis]. Univ. de Strasbourg.

Fleitout, L., and Froidevaux, C., 1980. Thermal and mechanical evolution of shear zones. J. Struct. Geol., 1/2:159-164.

Fleitout, L., Froidevaux, C., and Yuen, D., 1986. Active lithospheric thinning. Tectonophysics, 132:271-278.

Floyd, P. A., 1976. Review on geochemical data on rocks from the Lizard complex, Cornwall. Proc. Ussher Soc., 3:402-413.

Fortané, A., Duée, G., Lagabrielle, Y., and Coutelle, A., 1986. Lherzolites and the western "Chaînons Béarnais" (French Pyrenees): structural and paleogeographical pattern. Tectonophysics, 129:81-98.

Freer, R., Carpenter, M. A., Long, J.V.P., and Reed, S.J.B., 1982. "Null result" diffusion experiments with diopside: implications for pyroxene equilibria. Earth Planet. Sci. Lett., 52:285-292.
Frey, F. A., Suen, C. J., and Harlan, W. S., 1985. The Ronda high temperature peridotite: geochemistry and petrogenesis. Geochim. Cosmochim. Acta, 49:2469-2491.

Gaudichet, A., 1974. Etude pétrographique des lherzolites de la région d'Oloron Ste Marie (Pyrénées Atlantiques) [Thesis]. Univ. de Paris.

Green, D. H., 1964. The petrogenesis of the high-temperature peridotite intrusion in the Lizard area, Cornwall. J. Petrol., 5:134-188.

Harte, B., 1977. Rock nomenclature with particular relation to deformation and recrystallisation textures in olivine-bearing xenoliths. $J$. Geol., 85:279-288.

Irvine, T. N., 1965. Chromian spinel as a petrogenetic indicator. Part I, theory. Can. J. Earth Sci., 2:648-671.

1967. Chromian spinel as a petrogenetic indicator. Part II, petrologic applications. Can. J. Earth Sci., 4:71-103.

Jackson, E. D., 1961. Primary textures and mineral associations in the ultramafic zone of the Stillwater complex, Montana. Geol. Surv. Prof. Pap. U.S., 358.

Kirby, G. A., 1979. The Lizard complex as an ophiolite. Nature, 282: 58-61.

Kornprobst, J., 1969. Le massif ultrabasique des Beni Bouchera (Rif interne, Maroc). Contrib. Mineral. Petrol., 23:290-309.

Kornprobst, J., Ohnenstetter, D., and Ohnenstetter, M., 1981. Na and $\mathrm{Cr}$ contents in clinopyroxenes from peridotites: a possible discriminant between "sub-continental" and "sub-oceanic" mantle. Earth Planet. Sci. Lett., 53:241-254.

Kornprobst, J., Piboule, M., and Tabit, A., 1987a. Diversité des clinopyroxénites à grenat associées aux massifs ultramafiques orogéniques: éclogites, ariégites, griquaites et grospydites; une discussion. Bull. Soc. Geol. Fr., 8:345-351.

Kornprobst, J., Pineau, F., Degiovanni, R., and Dautria, J. M., 1987 b. Primary igneous graphite in ultramafic xenoliths-Part I: petrology of the cumulate suite in alkali basalt near Tissemt (Eggéré, Algerian Sahara). J. Petrol., 28:293-311.

Kornprobst, J., and Vielzeuf, D., 1984. Transcurrent crustal thinning: a mechanism for the uplift of deep continental crust/upper mantle associations. In Kornprobst, J. (Ed.), Kimberlites II: Amsterdam (Elsevier), 347-359.

Lasaga, A. C., 1983. Geospeedometry: an extension of geothermometry. In Sawena, S. K. (Ed.), Kinetics and Equilibrium in Mineral Reactions: Berlin (Springer-Verlag), 81-114.

Libourel, G., 1985. Le complexe de Santa Lucia di Mercurio (Corse) [Thesis]. Toulouse.

Loomis, T., 1972. Diapiric emplacement of the Ronda high temperature ultramafic intrusion, southern Spain. Geol. Soc. Am. Bull., 83: $2475-2596$.

Loubet, M., Shimizu, N., and Allègre, C. J., 1975. Rare earth elements in alpine peridotites. Contrib. Mineral. Petrol., 53:1-12.

Lundeen, M., 1978. Emplacement of the Ronda peridotite, Sierra Bermeja, Spain. Geol. Soc. Am. Bull., 89:172-180.

Matte, P., 1986. Tectonics and plate tectonics model for the Variscan Belt of Europe. Tectonophysics, 126:329-374.

Monchoux, P., 1970. Les lherzolites pyrénéennes: contribution à l'étude de leur minéralogie, de leur genèse et de leurs transformations [Thesis]. Toulouse.

Nicolas, A., Boudier, F., and Montigny, R., 1987. Structure of Zabargad Island and early rifting of the Red Sea. J. Geophys. Res., 92: 461-474.

Nicolas, A., and Poirier, J. P., 1976. Crystalline Plasticity and Solid State Flow in Metamorphic Rocks: New York (Wiley).

Obata, M., 1980. The Ronda peridotite: garnet-spinel and plagioclaselherzolite facies and the PT trajectories of a high-temperature mantle intrusion. J. Petrol., 21:533-572.

O'Hara, M. J., 1967. Mineral facies in ultrabasic rocks. In Wyllie, P. J. (Ed.), Ultramafic and Related Rocks: New York (Wiley), 7-18.

Ozawa, K., 1984. Olivine-spinel geospeedometry: analysis of diffusioncontrolled $\mathrm{Mg}-\mathrm{Fe}^{2+}$ exchange. Geochim. Cosmochim. Acta, 48: 2597-2611.

Podvin, P., 1983. Remobilisations chimiques successives dans les tectonites ophiolitiques et leurs gisements de chromite. Exemple du Massif du Humboldt (Nouvelle Calédonie) [Thesis]. Univ. de Paris.

Prinzhofer, A., 1981. Structure et pétrologie d'un cortège ophiolitique: le Massif du Sud (Nouvelle Calédonie). La transition manteau-croûte en milieu océanique [Thesis]. Univ. de Paris.

Ravier, J., 1964. Ariégites et eclogites. Bull. Mineral., 87:212-215. 
Reinhardt, B. M., 1969. On the genesis and emplacement of ophiolites in the Oman Mountains geosyncline. Schweiz. Mineral. Petrogr. Mitt., 49:1-30.

Rio, M., 1966. Observations sur deux gisements de lherzolite des Basses Pyrénées [Thesis]. Univ. de Paris.

Rothstein, A.T.V., 1971. A primary igneous texture from the Lizard peridotite, Cornwall. Geol. Mag., 108:393-398.

1977. The distribution and origin of primary textures in the Lizard peridotite, Cornwall. Proc. Geol. Assoc., 88(2):93-105.

1981. The primary crescumulates of the Lizard peridotite, Cornwall. Geol. Mag., 118:491-500.

Styles, M. T., and Kirby, G. A., 1980. New investigations of the Lizard Complex, Cornwall, England and a discussion of an ophiolitic model. In Panayiotou, A. (Ed.), Ophiolites Proc. Int. Ophiolite Symp. $1979,517-526$.

Tabit, A., 1986. Equilibre orthopyroxene-spinelle [Thesis]. Univ. Clermont Ferrand.
Tournon, J., 1984. Magmatismes du Mésozoïque à l'actuel en Amérique Centrale: l'exemple de Costa Rica, des ophiolites aux andésites. Mem. Sci. Terre Univ. Pierre et Marie Curie, 49.

Tubia, J. M., and Cuevas, J., 1986. High-temperature emplacement of the Los Reales peridotite nappe (Betic Cordillera, Spain). J. Struct. Geol., 8:473-482.

Vearncombe, J., 1980. The Lizard ophiolite and two phases of suboceanic deformation. In Panayiotou, A. (Ed.), Ophiolites Proc. Int. Ophiolite Symp. 1979, 527-537.

Vielzeuf, D., and Kornprobst, J., 1984. Crustal splitting and the emplacement of Pyrenean lherzolites and granulites. Earth Planet. Sci. Lett., 67:87-96.

Wernicke, B., 1985. Uniform-sense normal simple shear of the continental lithosphere. Can. J. Earth Sci., 22:108-125.

Date of initial receipt: 14 January 1987

Date of acceptance: 8 May 1987

Ms 103B-141 


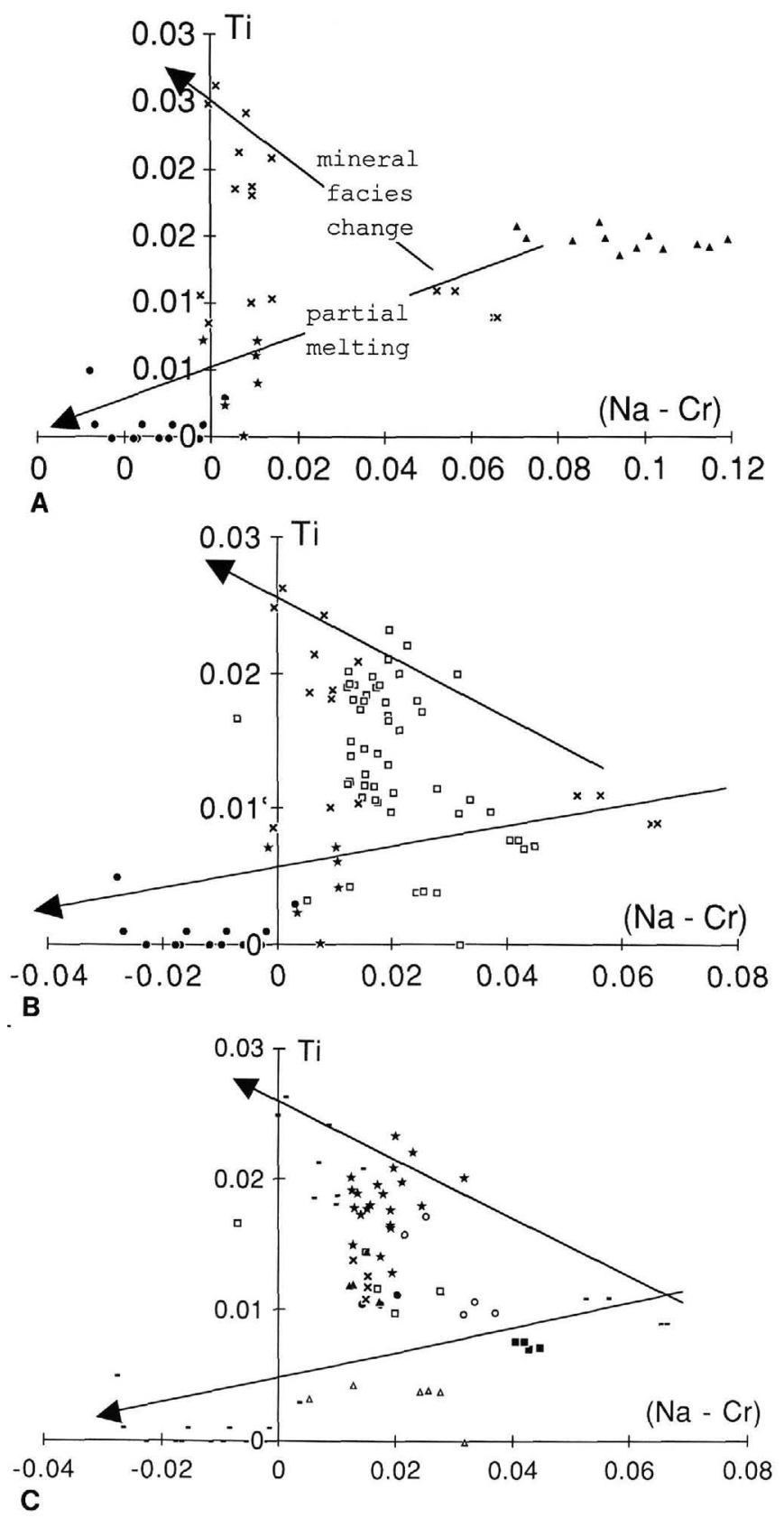

Figure 7. (Na-Cr) vs. Ti in clinopyroxene. A. Behavior of Ti in partialmelting event and mineral facies change. Open squares = Galicia margin; solid dots = northern Oman (Augé, 1983); solid squares = Lizard; crosses $=$ Ronda; solid triangles $=$ western Pyrenees; stars $=$ Santa Elena. B. Comparison of Galicia margin peridotite to peridotites from other low-pressure ultramafic bodies. Open squares = Galicia margin; solid dots = northern Oman (Augé, 1983); solid squares = Lizard; crosses = Ronda; solid triangles $=$ western Pyrenees; stars = Santa Elena. C. Samples from the Galicia margin peridotite. Sample identifications are given in Table 1. Solid dots = G4; open circles = G8; solid squares $=\mathrm{G} 11$; open squares $=\mathrm{G} 12$; solid triangles $=\mathrm{G} 13$; open triangles = G14; crosses = G16; stars = G19; bars = clinopyroxene from Ronda and northern Oman.

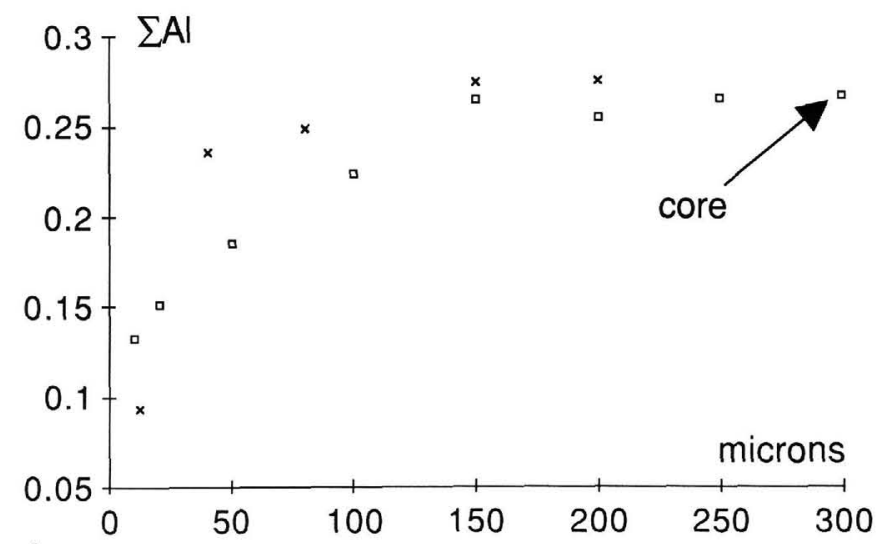

A

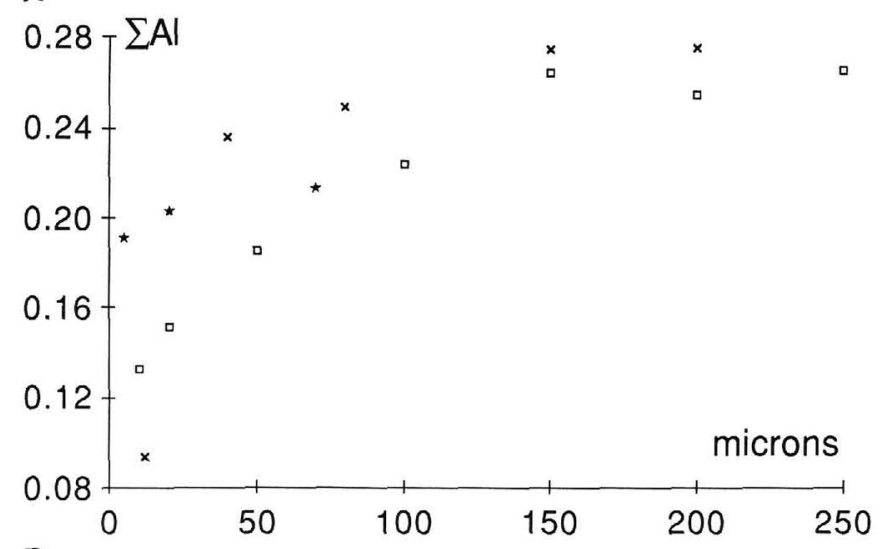

B

Figure 8. Concentration variation of $\Sigma \mathrm{Al}$ (vertical scale, cation per formula on 6 oxygens) across clinopyroxene phenoclasts. A. Galicia margin peridotite (G19; open squares) compared to Ronda samples (crosses). B. Galicia and Ronda peridotites compared to Santa Elena samples (stars). 


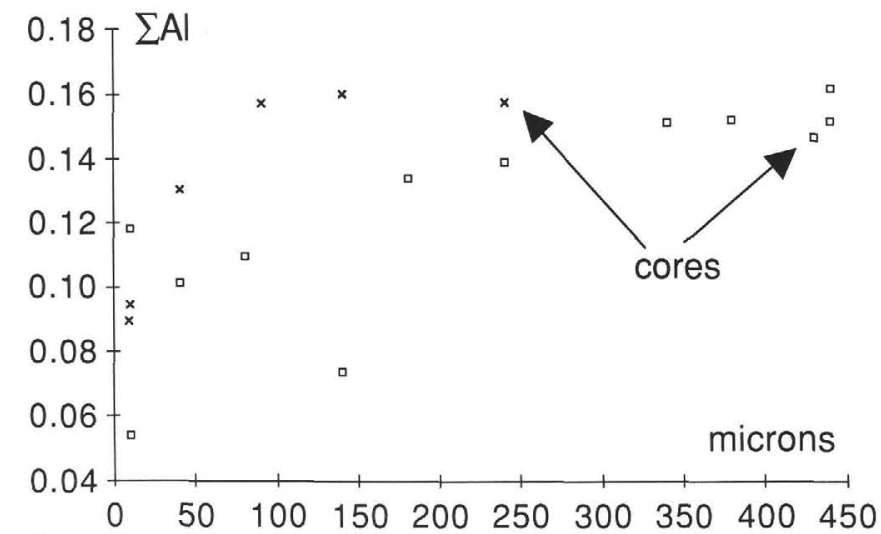
A
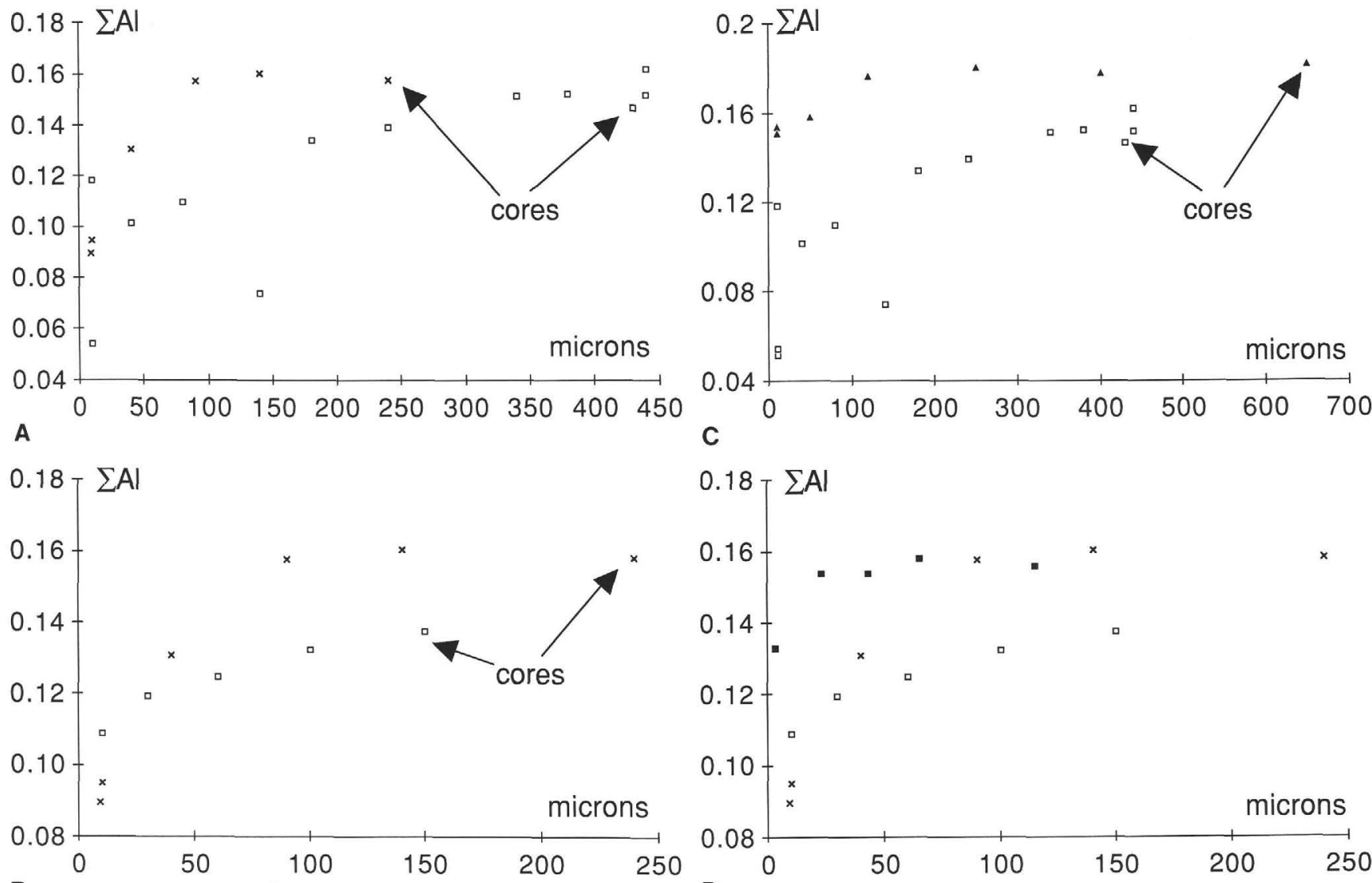

B

D

Figure 9. Concentration variation of $\Sigma \mathrm{Al}$ across orthopyroxene phenoclasts. A. Galicia margin peridotite (G19; open squares) compared to Ronda samples (crosses). B. Galicia margin peridotite (G11; open squares) compared to Ronda samples (crosses). C. Galicia margin peridotite (G19; open squares) compared to western Pyrenees samples (solid triangles). D. Galicia margin (open squares) and Ronda (crosses) peridotites compared to an ultramafic xenolith from alkali basalt at Tallante, Spain (solid squares). 

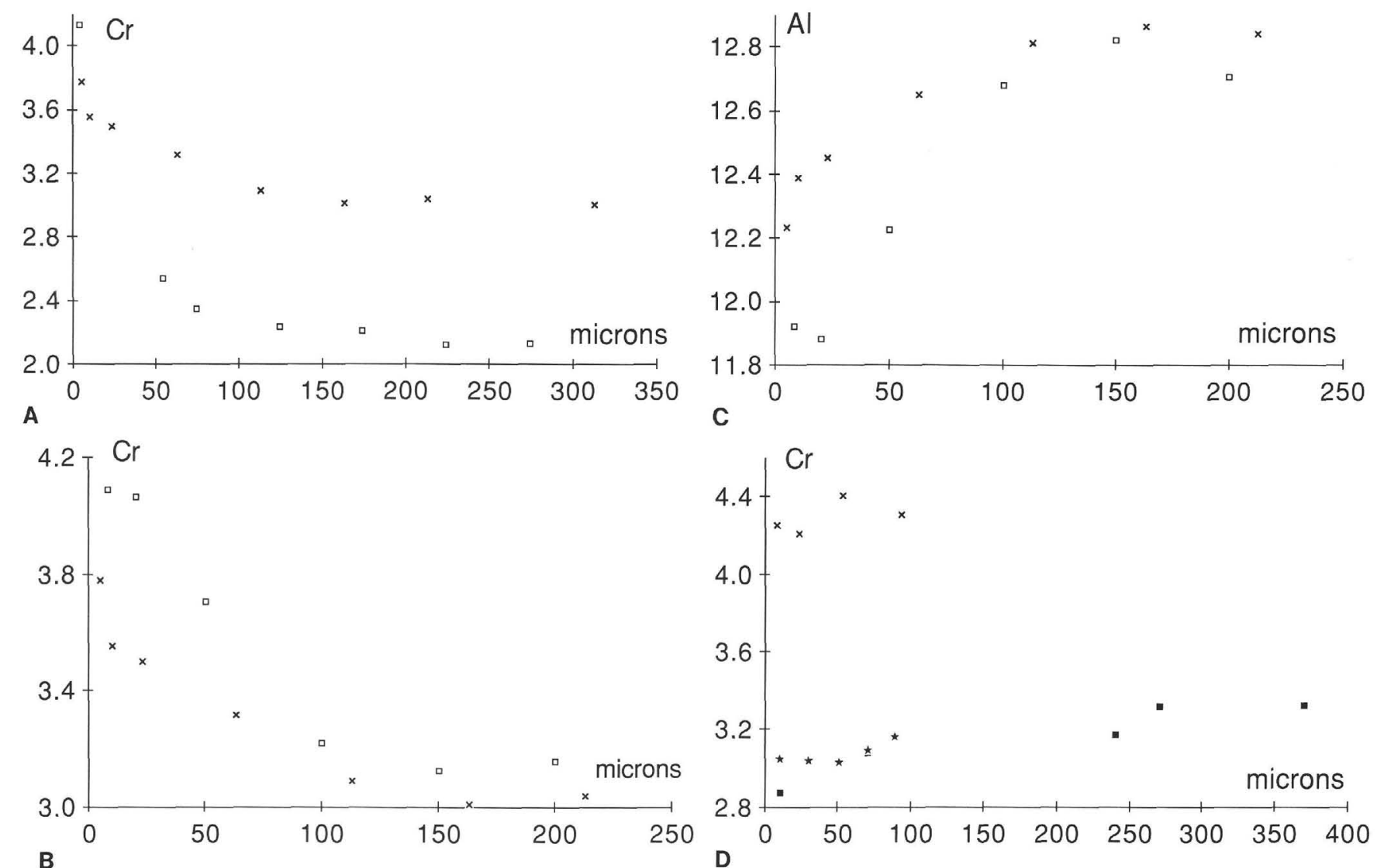

Figure 10. Concentration variations of $\mathrm{Cr}$ and $\mathrm{Al}$ (vertical scale; cation per formula on 24 oxygens) across spinel phenoclasts. A. Cr of Galicia margin peridotite (G19; open squares) compared to Ronda samples (crosses). B. Cr of Galicia margin peridotite (G13; open squares) compared to Ronda samples (crosses). C. Al of Galicia margin peridotite (G13; open squares) compared to Ronda samples (crosses). D. Cr of Galicia margin peridotite samples. Stars = G8; solid squares = G14; crosses = G16.

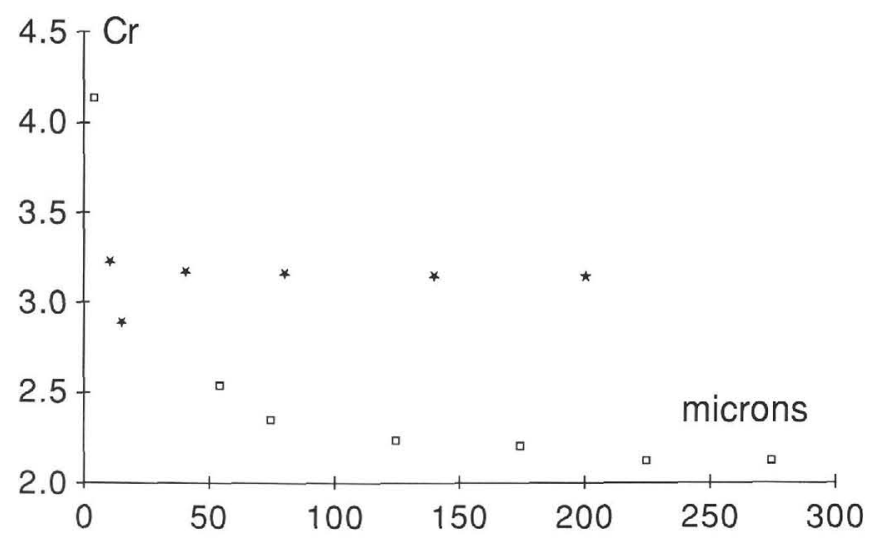

Figure 11. Concentration variation of $\mathrm{Cr}$ across spinel phenoclasts. Galicia peridotite (G19; open squares) compared to Santa Elena samples (stars). 


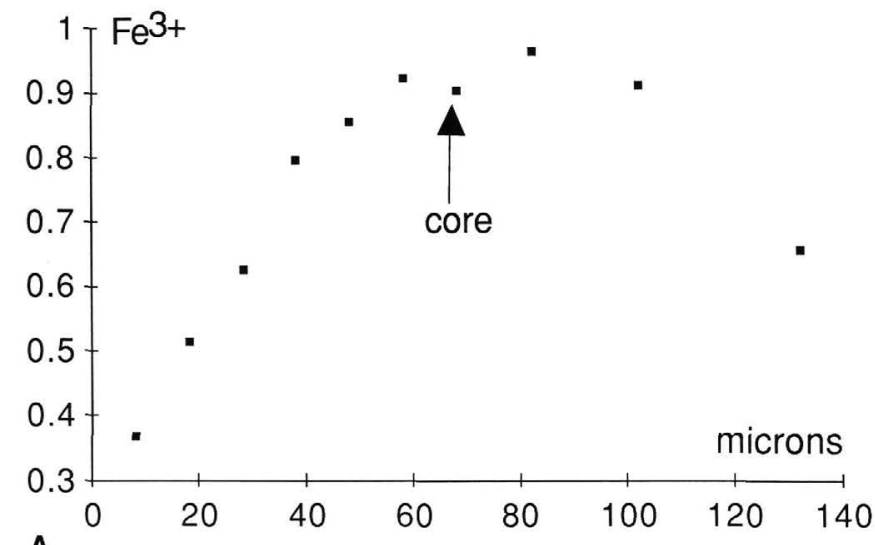

$$
\text { A }
$$
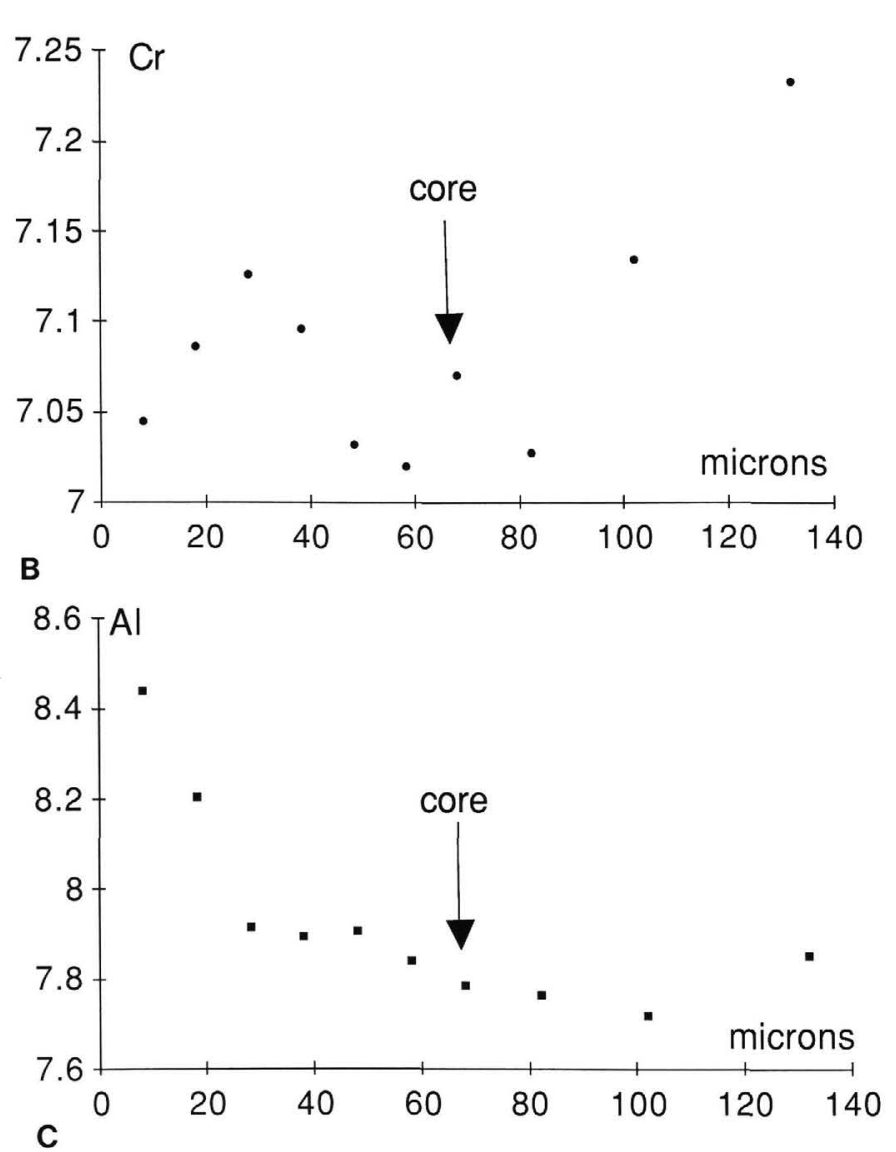

Figure 12. Concentration variations of $\mathrm{Fe}^{3+}, \mathrm{Cr}$, and $\mathrm{Al}$ across spinel phenoclast from Lizard Point peridotite. A. Bell-shaped behavior of $\mathrm{Fe}^{3+}$ (calculated by stoichiometry). B. Oscillatory zoning of Cr. C. Oscillatory zoning of Al. Note that the crystal is not symmetrical. 


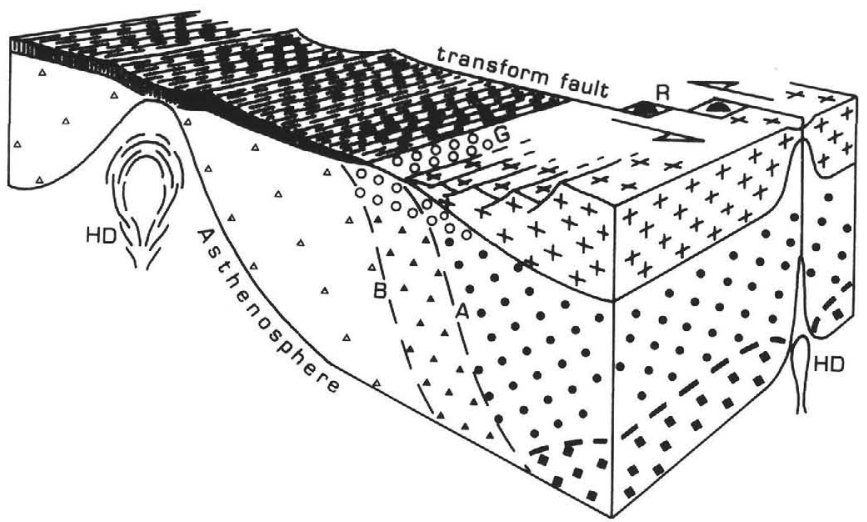

Figure 14. Block diagram illustrating the two different models of emplacement of the ultramafic bodies exemplified in this paper. The sketch does not aspire to be realistic but tries to clarify the structural relationships between the different mantle units. A major discontinuity within the subcontinental lithosphere (not shown here) would be consistent with Wernicke's (1985) model of extension. The peridotites of the Galicia margin $(G)$ belong to an elongate mantle unit on the seafloor between the oceanic and the continental crusts (see Boillot et al., this volume). They recrystallized in the plagioclase field during slow and moderate uplift and experienced minor partial melting during the rifting stage. These peridotites are far less depleted in incompatible elements than the oceanic lithosphere (shown on the left) that was the source of the oceanic crust. The peridotites of the Ronda type (R) relate to transcurrent faulting and crustal thinning. They were emplaced from more than $100 \mathrm{~km}$ depth as hot ultramafic diapirs that rose relatively quickly to the surface by (1) a perturbed convective asthenosphere close to the region where an oceanic ridge was developing (see Fleitout et al., 1986), (2) the greatly decreasing viscosity of the lithosphere and the lithospheric thinning related to the symmetrical diffusion of the heat mechanically produced along the transform fault (see Fleitout et al., 1980), and (3) extensional processes related to moderate removal of the two lithospheric plates along the transform fault (Kornprobst and Vielzeuf, 1984 ) and/or related to the formation of small pull-apart basins involving crustal thinning or splitting (Vielzeuf and Kornprobst, 1984) along the transform zone. Crosses = continental crust; stripes = oceanic crust; open circles = plagioclase-bearing peridotites; solid dots and solid squares = spinel- and garnet-lherzolites, respectively, relatively fertile in incompatible elements (subcontinental lithosphere); solid triangles = moderately depleted spinel-peridotites; open triangles = highly depleted peridotites (suboceanic lithosphere), source of the oceanic crust; $\mathrm{A}=$ the oldest partial-melting surface (i.e., lithosphere/asthenosphere boundary) during a rifting stage; $\mathrm{B}=$ an old partial-melting surface at the beginning of the rifting stage; $\mathrm{HD}=$ hot ultramafic diapirs. 